\title{
Source and distribution of naturally occurring arsenic in groundwater from Alberta's Southern Oil Sands Regions
}

\author{
Michael C. Moncur ${ }^{\mathrm{a}, \mathrm{b}}$, Dogan Paktunc ${ }^{\mathrm{c}, \mathrm{b}}$, S. Jean Birks ${ }^{\mathrm{a}, \mathrm{b}}$, Carol J. Ptacek ${ }^{\mathrm{b}}$, Brent Welsh ${ }^{\mathrm{d}}$, Yves \\ Thibault ${ }^{\mathrm{c}}$ \\ a Alberta Innovates-Technology Futures, 360-33 Street, NW, Calgary, AB, Canada, T6N 1E4 \\ jean.birks@albertainnovates.ca \\ ${ }^{\mathrm{b}}$ Department of Earth and Environmental Sciences, University of Waterloo, 200 University \\ Avenue West, Waterloo, Ontario, Canada, N2L 3G \\ ptacek@uwaterloo.ca
}

${ }^{\mathrm{c} C A N M E T ~ M i n i n g ~ a n d ~ M i n e r a l ~ S c i e n c e s ~ L a b o r a t o r y, ~} 555$ Booth Street, Ottawa, ON, Canada, K1A 0G1

dpaktunc@NRCan.gc.ca

Yves.Thibault@NRCan.gc.ca

dAlberta Energy Regulator, Suite 402, 4999-98 Avenue, NW, Edmonton, AB, Canada, T6B 2X3

brent.welsh@aer.ca

*Corresponding author. Tel: (403) 210-5368 Fax: (403) 210-5395

E-mail address: michael.moncur@albertainnovates.ca

Water Management, Alberta Innovates-Technology Futures, 360-33 Street, NW, Calgary, AB, Canada, T6N 1E4

Keywords: arsenic; speciation; arsenian pyrite; iron reduction; XANES; isotopes 


\begin{abstract}
Arsenic (As) concentrations as high as $179 \mu \mathrm{g} / \mathrm{L}$, have been observed in shallow groundwater in the Alberta's Southern Oil Sand Regions. The geology of this area of Alberta includes a thick cover (up to $200 \mathrm{~m}$ ) of unconsolidated glacial deposits, with a number of regional interglacial sand and gravel aquifers, underlain by marine shale. Arsenic concentrations observed in 216 unconsolidated sediment samples ranged between 1 to $17 \mathrm{ppm}$. A survey of over 800 water wells sampled for As in the area found that $50 \%$ of the wells contained As concentrations exceeding drinking water guidelines of $10 \mu \mathrm{g} / \mathrm{L}$. Higher As concentrations in groundwater were associated with reducing conditions. Measurements of As speciation from 175 groundwater samples indicate that As(III) was the dominant species in $74 \%$ of the wells. Speciation model calculations showed that the majority of groundwater samples were undersaturated with respect to ferrihydrite, suggesting that reductive dissolution of Fe-oxyhydroxides may be the source of some of the As in groundwater. Detailed mineralogical characterization of sediment samples collected from two formations revealed the presence of fresh framboidal pyrite in the deeper unoxidized sediments. Electron microprobe analysis employing wavelength dispersive spectrometry indicated that the framboidal pyrite has variable As content with an average As concentration of $530 \mathrm{ppm}$, reaching up to $1840 \mathrm{ppm}$. In contrast, the oxidized sediments did not contain framboidal pyrite, but exhibited spheroidal Fe-oxyhydroxide grains with elevated As concentrations. The habit and composition suggest that these Fe-oxyhydroxide grains in the oxidized sediment were an alteration product of former framboidal pyrite grains. X-ray absorption near edge spectroscopy (XANES) indicated that the oxidized sediments are dominated by As(V) species having spectral features similar to those of goethite or ferrihydrite with adsorbed As, suggesting that Fe-oxyhydroxides are the dominant As carriers. XANES
\end{abstract}


spectra collected on unoxidized sediment samples, in contrast, indicated the presence of a reduced As species (As(-I)) characteristic of arsenopyrite and arsenian pyrite. The results of the mineralogical analyses indicate that the oxidation of frambroidal pyrite during weathering may be the source of As released to shallow aquifers in this region. 


\section{Introduction}

Arsenic occurs in the environment in oxidation states of -III, -I, 0, III and V. In sulfide minerals such as arsenian pyrite $\left[\mathrm{FeS}_{2}\right]$ and arsenopyrite $[\mathrm{FeAsS}]$, As is in the As(-I) oxidation state (Campbell and Nordstrom, 2014). In natural groundwater, the most prevalent oxidation states of As are oxyanions of arsenite $[\mathrm{As}(\mathrm{III})]$ and arsenate $[\mathrm{As}(\mathrm{V})]$. Aerobic waters are dominated by As(V) species whereas As(III) is the principal species in anaerobic environments (Nordstrom, 2002). Under circumneutral $\mathrm{pH}$, both species have an affinity for Fe-oxyhydroxide surfaces, but because As(III) is not as strongly adsorbed, it is more mobile in reducing aqueous environments than As(V) (Dixit and Herring, 2003). Both As(III) and As(V) are toxic (Amend et al., 2014; Leybourne et al., 2014), with As(III) being 25-60 times more toxic than As(V) (Korte and Fernando, 1991).

After contamination of drinking water by pathogenic organisms, elevated As concentrations in groundwater is the second most recognized global health hazard in drinking water (Johnston et al., 2001; van Halem et al 2009). It is estimated that over 150 million people worldwide are exposed to concentrations of geogenic arsenic in drinking water that exceed the World Health Organization (WHO) limit of $10 \mu \mathrm{g} \mathrm{L}^{-1}$ (Nordstrom, 2002; Smedley and Kinniburg, 2002; Mitchell, 2014). Although Bangladesh is one of the most recognized regions of As contaminated groundwater (eg. Nickson et al., 2000; Anawar et al., 2003; Harvey et al., 2006, Van Green et al., 2008; Jung et al., 2012), concentrations of As in groundwater exceeding WHO guidelines have been measured in over 70 countries on nearly every continent or major land mass (Barringer and Reilly, 2013).

Estimates of the population in Canada exposed to groundwater As concentrations exceeding the Canadian drinking water guidelines of $10 \mu \mathrm{g} \mathrm{L}^{-1}$ (Health Canada, 2012) are less 
documented. However, naturally occurring As has been documented at concentrations that exceed these guidelines in all provinces and one territory (Table 1). In western Canada, elevated As concentrations are typically associated with igneous and metamorphic bedrock aquifers, and associated glaciofluvial and fluvial sediments (Boyle et al., 1998; Bolton and Beckie, 2011). In eastern Canada, elevated As concentrations have been associated with metasedimentary bedrock aquifers in New Brunswick and Nova Scotia (Bottomley, 1984), igneous bedrock aquifers in Newfoundland, and sandstone aquifers in Prince Edward Island (Somers et al., 1999). Across the Prairie provinces, elevated As concentrations in groundwater are typically observed in glaciofluvial sediments (Lemay et al., 2005; Thompson et al., 1999; Moore, 2005), although groundwater obtained from some wells completed in sandstone and shale aquifers (Cheung et al., 2009) and produced-water from deep oil-field wells (White et al., 1963; Moncur, 2010) have elevated As. Anthropogenic sources of As in groundwater have been reported in many parts of Canada near facilities for wood treatment, gold mining operations (Wang and Mulligan, 2006), waste pond seepage from hydrofluoric acid production and enhanced oil recovery using thermal steam injection methods (Fennell, 2008). For example, As concentrations up to $2050 \mu \mathrm{g} / \mathrm{L}$ were reported for groundwater down-gradient from a Au-mine tailings impoundment in NW Ontario (Ross et al., 1999). 
Table 1. Examples of natural and anthropogenic occurrences of As in groundwater across Canada.

\begin{tabular}{|c|c|c|c|}
\hline Location & Rock Type/Aquifer & Conc. $\mu \mathrm{g} \mathrm{L}^{-1}$ & Reference \\
\hline \multicolumn{4}{|c|}{ Geogenic As source to groundwater } \\
\hline $\begin{array}{l}\text { Bowen Island, British } \\
\text { Columbia (BC) }\end{array}$ & $\begin{array}{l}\text { Metavolcanic and metasediments } \\
\text { with sulfides }\end{array}$ & $1-580$ & Boyle et al., 1998 \\
\hline Langley, BC & Glaciofluvial/marine clay & $<1-276$ & $\begin{array}{l}\text { Cavalanti de Albuquerque } \\
\text { et al., } 2012\end{array}$ \\
\hline Southern West Coast, BC & $\begin{array}{l}\text { Igneous bedrock with sulfides and } \\
\text { fluvial sediments }\end{array}$ & $<1-2440$ & $\begin{array}{l}\text { Carmichael \& Clarkson, } \\
\text { 1995; Mattu \& Schreier, } \\
\text { 2000; Bolton \& Beckie, } \\
2011\end{array}$ \\
\hline Meager Creek, BC & Geothermal hot spring water & $237-303$ & Koch et al., 1999 \\
\hline $\begin{array}{l}\text { Lussier, Fairmont \& } \\
\text { Radium Hot Springs, BC }\end{array}$ & Geothermal hot spring water & $\begin{array}{c}92,74-88,234 \\
\text { (respectively) }\end{array}$ & $\begin{array}{l}\text { Moncur, } 2013 \text { unpublished } \\
\text { data }\end{array}$ \\
\hline Alberta (AB) & Glaciofluvial/ sedimentary bedrock & $<1-119$ & Fitzgerald et al., 2001 \\
\hline $\begin{array}{l}\text { Cold Lake-Beaver River } \\
\text { Basin, AB }\end{array}$ & Glaciofluvial & $<10-361$ & $\begin{array}{l}\text { Stein et al., 2000; Lemay et } \\
\text { al., } 2005\end{array}$ \\
\hline $\begin{array}{l}\text { Southern Athabasca Oils } \\
\text { Sands Region, AB }\end{array}$ & Glaciofluvial & $<10-30$ & Lemay, 2003 \\
\hline Central AB & Glaciofluvial/sandstone & $<1-780$ & AHW, 2000 \\
\hline South-Central AB & Cretaceous sandstone/shale & $<1-165$ & Cheung et al., 2009 \\
\hline Ellis Pool, AB & Deep oilfield brine & 230 & White et al., 1963 \\
\hline Saskatchewan (SK) & Glaciofluvial & $<1-117$ & Thompson et al., 1999 \\
\hline Birsay, SK & Glacial till pore water & $3-99$ & Yan et al, 2000 \\
\hline Virden, Manitoba (MB) & Glaciofluvial & $38-44$ & Moore, 2005 \\
\hline Ontario $(\mathrm{ON})$ & Various & $<2.5-68$ & Health Canada, 2006 \\
\hline Quebec (QC) & Not specified & $<10-330$ & McGuigan et al., 2010 \\
\hline New Brunswick & Igneous and metasediment bedrock & up to 1050 & Bottomly, 1984 \\
\hline Prince Edward Island & Permian sandstone & $<1-26$ & Somers et al., 1999 \\
\hline Nova Scotia & $\begin{array}{l}\text { Metasediment bedrock with } \\
\text { sulfides }\end{array}$ & $3-5000$ & Meranger et al., 1984 \\
\hline Newfoundland & Igneous and sedimentary bedrock & up to 769 & $\begin{array}{l}\text { Rageh et al., 2007; Serpa et } \\
\text { al., } 2009\end{array}$ \\
\hline Carcross, Yukon & Glaciofluvial & $12-27$ & Dayton \& Knight, 2010 \\
\hline \multicolumn{4}{|c|}{ Anthropogenic As source to groundwater } \\
\hline Montreal, QC & Glaciofluvial-wood preservative & $1-79$ & Zagury et al., 2003 \\
\hline $\begin{array}{l}\text { Cold Lake Oil Sands } \\
\text { Region, AB }\end{array}$ & $\begin{array}{l}\text { Glaciofluvial-enhanced thermal } \\
\text { recovery of bitumen operations }\end{array}$ & $5-324$ & $\begin{array}{l}\text { CNRL, 2005; Fennell, } \\
2008\end{array}$ \\
\hline Amherstburg, ON & $\begin{array}{l}\text { Carbonate bedrock-hydrofluoric } \\
\text { acid production }\end{array}$ & up to 206 & Windsor Star, 2006 \\
\hline $\begin{array}{l}\text { Gold mine, Balmertown, } \\
\text { ON }\end{array}$ & $\begin{array}{l}\text { Sulfide mine tailings porewater- } \\
\text { neutral rock drainage (NRD) }\end{array}$ & $300-100,000$ & McCreadie et al., 2000 \\
\hline $\begin{array}{l}\text { Zn-Cu mine, Sherridon, } \\
\text { MB }\end{array}$ & $\begin{array}{l}\text { Sulfide mine tailings porewater- } \\
\text { acid rock drainage }\end{array}$ & $<10-50,000$ & Moncur et al., 2005 \\
\hline $\begin{array}{l}\text { Gold mine, Yellowknife, } \\
\text { NT }\end{array}$ & $\begin{array}{l}\text { Lake sediment porewater impacted } \\
\text { by mining operation }\end{array}$ & $16-947$ & Andrade et al., 2010 \\
\hline Gold mine, Bralorne, $\mathrm{BC}$ & $\begin{array}{l}\text { Flooded underground mine } \\
\text { workings - NRD }\end{array}$ & up to 5898 & Desbarats et al., 2014 \\
\hline
\end{tabular}

Elevated As concentrations have been reported in many small-scale groundwater

investigations in the Cold Lake-Beaver River Basin (CLBR) in east-central Alberta, but previous 
studies did not clearly identify the spatial extent of this groundwater problem or identify whether the elevated concentrations were due to natural geogenic sources, or anthropogenic activities. An early study by Nriagu (1998) sampled 51 residential wells and found that $40 \%$ of the wells had As concentrations exceeding Canadian drinking water guidelines of $10 \mu \mathrm{g} / \mathrm{L}$. Follow up studies of residential wells in the CLBR basin by Alberta Health and Wellness (AHW 2000) and Stein et al. (2000), found that $50 \%$ of the 59 wells and $54 \%$ of the 35 wells sampled respectively, contained As concentrations in groundwater exceeding $10 \mu \mathrm{g} / \mathrm{L}$. Lemay et al. (2005) was the first to map the distribution of As concentrations in groundwater across the CLBR basin spatially and within individual formations, but did not provide information regarding the number of wells exceeding drinking water guidelines for As. A study by AHW (2014) that surveyed 152 wells in the CLBR basin found that $48 \%$ of groundwater from residential wells contained As concentrations that exceeded guidelines, with As(III) as the dominant species. Javed et al. (2014) characterized sediments from the CLBR basin and observed both arsenian pyrite and arseopyrite. Arsenic was also found to be adsorbed to sediments and bound to crystalline oxide minerals. The objective of this investigation is the integration of existing and newly collected As groundwater data, including As speciation measurements, with major ion and trace element data to understand processes controlling the spatial distribution of As concentrations in groundwater across the CLBR basin and identify areas of concern. A second objective was to determine sources and potential controls of As mobility in groundwater using geochemical modeling and detailed solidphase and mineralogical analyses from available aquifer sediments.

\section{Study area}

The Alberta portion of CLBR basin is approximately $22,000 \mathrm{~km}^{2}$, located $400 \mathrm{~km}$ northeast of Calgary (Fig. 1). The basin encompasses a portion of the Southern Oil Sands Region and the 
Cold Lake Oil Sands Region (Fig. 1). Agricultural lands cover one-third of the watershed. The area also includes considerable heavy oil and gas extraction, with numerous active energy wells (Fig. 1). Commercial scale thermal in situ oil sands projects are present west and northwest of Cold Lake. Groundwater is extensively used as a source of water in the CLBR region for industrial, agricultural, municipal, and domestic purposes (AESRD, 2013). 

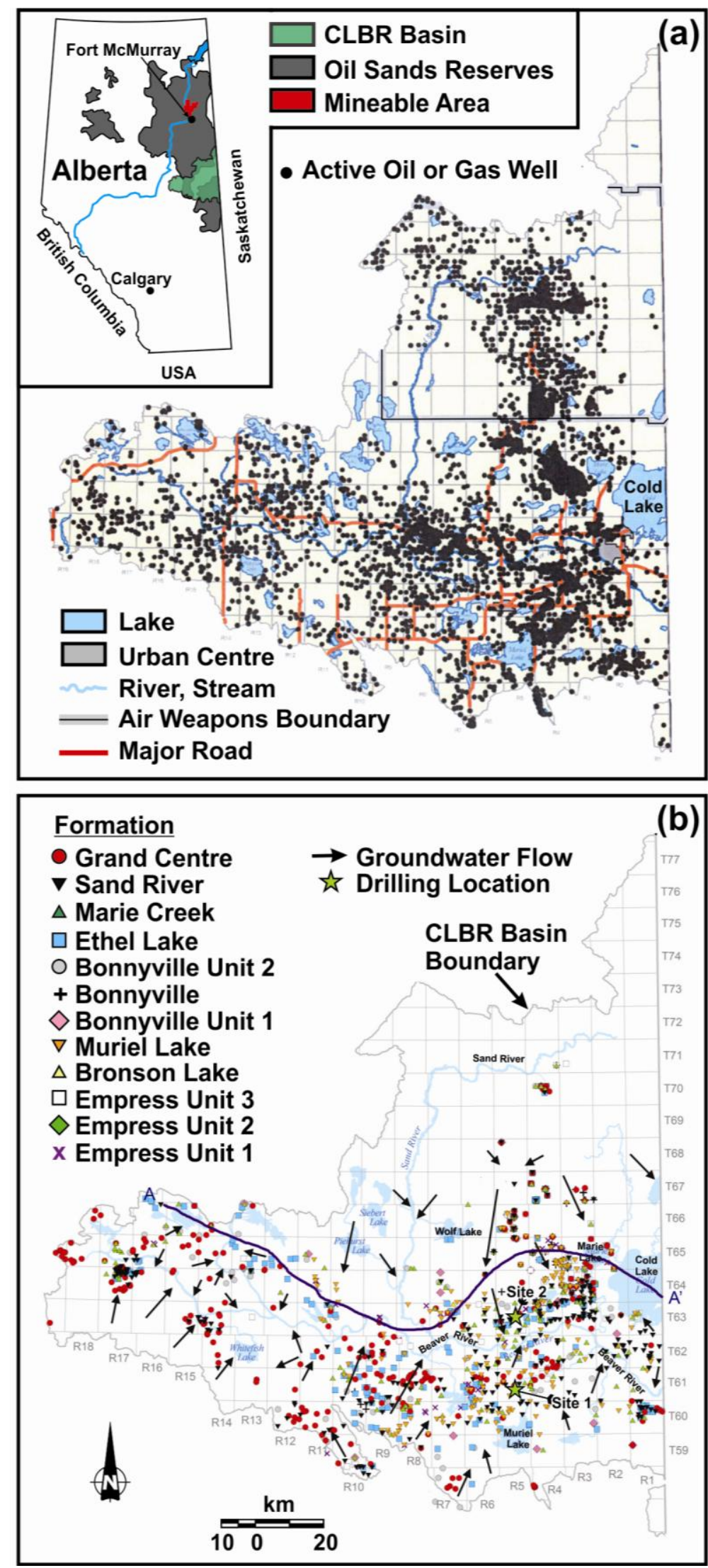
Fig. 1. Maps show (a) distribution of active energy wells, revised after Lemay (2005). (b) regional groundwater flow and the location of water wells (symbols are differentiated by geological formation) used in this study. Inset shows the extent of the oil sands and location of the Cold Lake-Beaver River Basin in Alberta, Canada.

\section{Geological and hydrogeological setting}

The general stratigraphy beneath the CLBR basin is comprised of 25 to $225 \mathrm{~m}$ of unconsolidated sediments with the basal deposits composed of Neogene sand and gravel overlain by alternating till and sand and gravel sequences of glacial Quaternary deposits (Fig. 2). A clay-till unit blankets most of the upper surface of the CLBR basin. These sediments unconformably rest on thick (> $200 \mathrm{~m}$ ) Cretaceous organic-rich marine shale of the Lea Park and Colorado Group (Prior et al., 2013). Neogene and Quaternary stratigraphy of the area was mapped by Andriashek and Fenton (1989), Andriashek (2003), and Parks et al. (2005). Based on their observations and lithological description of each formation or unit, twelve distinct hydrostratic units were identified as regional aquifers and aquitards (Table 2).

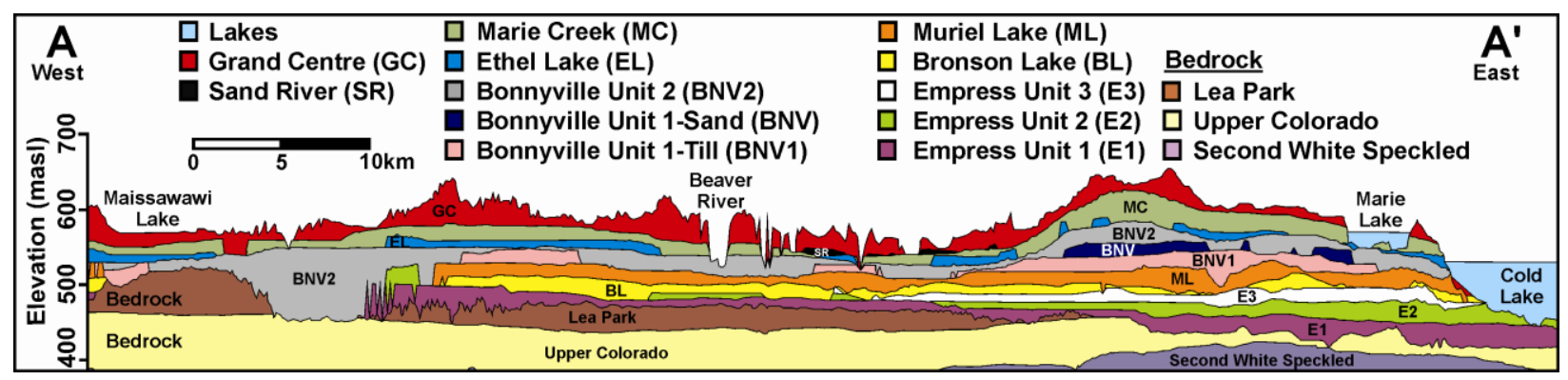

Fig. 2. Cross-section, A-A' from Fig. 1b, showing the distribution of stratigraphic units across the Cold Lake-Beaver River Basin (revised after Parks et al., 2005).

Bedrock incisions from preglacial and glacial drainage has produced a network of buried paleovalley and buried glaciofluvial channel aquifers throughout the CLBR basin. As a result, regional groundwater flow in aquifers is constrained by surficial topography, deep surface water bodies, and bedrock topography (Parks et al., 2005). Recharge occurs in the uplands, particularly in the north, with discharge and flowing artesian conditions occurring in the low lands near the 
confluence of the Sand and Beaver Rivers, eastern reaches of the Beaver River, and near some lakes (Fig. 1). Cold Lake is approximately $100 \mathrm{~m}$ deep and represents both a groundwater discharge site as well as a source of recharge for hydraulically connected aquifers (Fig. 2). In the deeper Empress aquifers, flow is laterally confined by bedrock barrier boundaries, whereas shallower aquifers tend to exhibit stronger influences from topography. Cross-formational flow between shallow and deeper aquifers occurs across till sheets mostly at hydraulic windows associated with cross-cutting sands and gravels deposited during glacial and more recent erosional events (Parks et al., 2005). In general, groundwater flow in all aquifers is downward along the flanks of the CLBR watershed and laterally directed towards the Beaver River downstream of the Sand River confluence, signifying a strong influence from surficial topography (Fig. 1).

Table 2. Physical properties of the eight formations in the CLBR glacial drift deposits (revised after Parks et al., 2005). N refers to the Neogene Period.

\begin{tabular}{|c|c|c|c|c|c|c|}
\hline \multirow{12}{*}{ 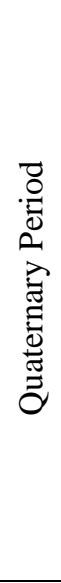 } & Formation & Lithology & Hydrogeology & $\begin{array}{c}\text { Area } \\
\left(\mathrm{km}^{2}\right)\end{array}$ & $\begin{array}{c}\text { Volume } \\
\left(\mathrm{km}^{2}\right)\end{array}$ & $\begin{array}{c}\text { Thickness } \\
\text { (m) }\end{array}$ \\
\hline & Grand Center (GC) & till & aquitard & 16,000 & 810 & $1-150$ \\
\hline & Sand River (SR) & sand/silt & aquifer & 5,000 & 13 & $1-85$ \\
\hline & Marie Creek (MC) & till & aquitard & 12,000 & 300 & $1-100$ \\
\hline & Ethel Lake (EL) & silt/sand/gravel & aquifer & 4,600 & 31 & $1-65$ \\
\hline & Bonnyville Unit 2 (BNV2) & till & aquitard & 12,700 & 310 & $1-150$ \\
\hline & Bonnyville (BNV) & sand/gravel & aquifer & 1,100 & 8 & $1-65$ \\
\hline & Bonnyville Unit 1 (BNV1) & till & aquitard & 5,200 & 78 & $1-95$ \\
\hline & Muriel Lake (ML) & sand/silt/gravel & aquifer & 4,800 & 65 & $1-50$ \\
\hline & Bronson Lake (BL) & diamicton/clay & aquitard & 3,200 & 34 & $1-100$ \\
\hline & Empress Unit 3 (E3) & sand/gravel & aquifer & 1,600 & 19 & $1-110$ \\
\hline & Empress Unit 2 (E2) & clay/silt & aquitard & 1,100 & 13 & $1-55$ \\
\hline $\bar{z}$ & Empress Unit 1 (E1) & sand/gravel & aquifer & 2,200 & 22 & $1-55$ \\
\hline
\end{tabular}

\section{Methods}

\subsection{Groundwater Chemistry}

The majority of the groundwater geochemistry data used in this study was provided by Alberta Environment and Sustainable Resource Development that included data from the Alberta Water 
Well Information Database (http://environment.alberta.ca/01314.html), AHW (2000), Beaver River Watershed Alliance database, and a number of industry studies. The groundwater database for the CLBR basin included 527,349 entries containing groundwater geochemistry and /or water levels. This database was filtered to remove entries where depth, or latitude and longitude were missing and geochemistry data with charge balance errors exceeding $10 \%$ and industrial monitoring wells that could potentially be impacted by enhanced thermal in situ oil recovery operations. Statistical analyses such as the median, mean, maximum, minimum, and standard deviation were determined for wells that were sampled multiple times. The final data set was reduced to 1537 wells with geochemistry including $\mathrm{pH}$, alkalinity and major anion and cations, 779 of which also had As concentration data. Additional groundwater chemistry was added to the data set from AHW (2014) and this study to ensure the most completed data set was interpreted. Alberta Environment provided geochemistry data from their Groundwater Observation Well Network (GOWN), including radiogenic isotopes of ${ }^{14} \mathrm{C}_{\text {DIC }}$ and $\delta{ }^{13} \mathrm{C}_{\text {DIC }}$ and stable isotopes of $\delta^{34} \mathrm{~S}_{-} \mathrm{SO}_{4}$. In total 816 wells with As concentrations were used for mapping.

A total of 13 groundwater wells were sampled during this study using a peristaltic pump and $6.4 \mathrm{~mm}$ diameter (1/4-inch) polyethylene tubing. Sample tubing was lowered into the well screen and pumped at a low-flow rate following the method of Puls and Barcelona (1996). Water levels were periodically measured during pumping to ensure that no or minimal drawdown was occurring. Measurements of $\mathrm{pH}, \mathrm{Eh}$, temperature, electrical conductivity and dissolved oxygen (DO) were made in the field using a Hydrolab with probes sealed in a flow-through cell. All probes in the Hydrolab were calibrated prior to sampling. Water samples were collected when $\mathrm{pH}$ and Eh values stabilized. Water samples were collected for major anions and cations, trace metals, dissolved organic carbon (DOC) from each well. All water samples were filtered with 
$0.45 \mu \mathrm{m}$ polyethersulphone filters and stored in prewashed Nalgene bottles. One aliquot of water was acidified with $12 \mathrm{~N}$ trace-metal grade $\mathrm{HNO}_{3}$ to a $\mathrm{pH}$ of $<1$ for cation and dissolved metals analysis, and other aliquots were left unacidified. All water samples were immediately refrigerated at $4{ }^{\circ} \mathrm{C}$ until analyses. Water samples were analyzed using inductively coupled plasma - optical emission spectrometry (ICP-OES) analysis for major cations, inductively coupled plasma-mass spectrometry (ICP-MS) for trace metals, and ion chromatography (IC) for anions. Combustion and infrared detection was used for DOC analysis. Measurements of alkalinity were made in the field on filtered samples using a Hach digital titrator and bromcresol green / methyl red indicator and $0.16 \mathrm{~N} \mathrm{H}_{2} \mathrm{SO}_{4}$.

Maps showing the spatial distribution of As concentrations in groundwater were created using ArcGIS. Shape files for all geological formations in the CLBR basin were provided by the Alberta Geological Survey. Arsenic data was mapped by individual formations/aquifers. All formation units were mapped except the Bonnyville Unit 1 and 2, Bronson Lake, Empress 2 Formations and bedrock due to limited data points.

\subsection{Arsenic Speciation}

There was a much smaller subset of data with speciated As analysis available from groundwater, including the AHW (2014), the GOWN wells and this study. During the AHW (2014) survey, 132 groundwater samples were speciated into $\mathrm{As}(\mathrm{III})$ and $\mathrm{As}(\mathrm{V})$ at the University of Alberta by using a HPLC-ICP-MS following the methods of Le et al. (1998) and Gong et al. (2006). An additional 34 samples from the GOWN wells and nine from this study were speciated into As(III) and As(V) in the field using a modified anion-exchange method of Ficklin (1983) followed by ICP-MS analyses.

\subsection{Geochemical Modeling}


The geochemical model PHREEQC 2.18 (Parkhurst and Appelo, 1999) using the WATEQ4F (Ball and Nordstrom, 1991) database was used to elucidate mineral phases that may be controlling As concentrations in the groundwater. PHREEQC is an equilibrium/mass-transfer model that provides calculations of saturation indices (SI) for discrete mineral phases. To calculate SI for this study, the minimum parameters required from a groundwater sample included pH, Eh, alkalinity $\left(\mathrm{mg} \mathrm{L}^{-1} \mathrm{CaCO}_{3}\right), \mathrm{Ca}, \mathrm{K}, \mathrm{Mg}, \mathrm{Na}, \mathrm{SO}_{4}{ }^{2-}, \mathrm{Cl}, \mathrm{Al}, \mathrm{Fe}, \mathrm{As}$ and temperature. For wells with multiple sampling events, the most recent or most complete data set was used for modeling. In total, groundwater speciation calculations were made for groundwater samples collected from 605 wells. The computer program NETPATH (Plummer et al., 1994; Parkhurst and Charlton, 2008) was used to adjust ${ }^{14} \mathrm{C}_{\mathrm{DIC}}$ groundwater ages.

\subsection{Solid phase analyses and mineralogy}

Solid phase concentrations of As in sediments from the CLBR basin were obtained from Andriashek (2000; n=175) and Fennell (2008; n=21). In addition, we analyzed 26 sediment samples for total metal concentrations using $\mathrm{HF} / \mathrm{HNO}_{3}$ extraction followed by ICP-MS. Sediments were collected at two locations in the CLBR basin (Fig. 1b) using an auger drill rig equipped with a split-spoon sampler described by Moncur (2010). Sediment samples were collected every $0.25 \mathrm{~m}$ over the first $3 \mathrm{~m}$ of drilling followed by sampling at $0.5 \mathrm{~m}$ intervals for the remaining depths. Samples were collected from Site 1 and Site 2 to depths of $15 \mathrm{~m}$ and 13.5 m, respectively (Fig. 1b). After collection, samples were immediately frozen.

Samples for mineralogical analysis were shipped frozen to the laboratory where they were air-dried, de-agglomerated, homogenized and split into representative fractions. Eleven sediment samples were analyzed from Site 1, and four sediment samples were analyzed from Site 2. Primary crystalline phases were determined for all samples by X-ray diffraction (XRD) 
using a RIGAKU D/MAX 2500 rotating-anode powder diffractometer. More detailed identification of individual phases in the secondary precipitates was made using a Rigaku Rapid II rotating anode micro-XRD. For some samples, mineral species identified by XRD were confirmed by energy -dispersive spectrometry (EDS) using a JEOL JXA 8900 electron probe micro-analyzer (EPMA) to provide qualitative information about the composition of the main mineral phases observed in the polished section. Backscattered electron imaging (BSE) and quantitative wavelength-dispersive X-ray spectrometry (WDS) were used to locate and determine the compositions of the main carriers of As. X-ray absorption fine structure spectroscopy (XANES) experiments were carried out at the bending magnet beamline 20-BM at sector 20 of the Advanced Photon Source (APS), Argonne, IL, USA. XANES was used to determine the oxidation states of As mineral phases in two sediment samples collected at 5.5 and $6 \mathrm{~m}$ depths at Site 1 and two sediment samples collected at 1 and $11.5 \mathrm{~m}$ depths at Site 2 (Fig. 1b). Finely ground and homogenized samples were loaded into Teflon sample holders with Mylar windows. Experiments were carried out at room temperature in the fluorescence mode using a Canberra 13-element detector. A Au foil was used for energy calibration for As K-edge XAFS measurements. Between five to eight scans were made on each sample. Data reduction and analysis were performed with ATHENA (Ravel and Newville 2005). The least-squares fitting assessment of the XANES spectra were performed with LSFitXAFS (Paktunc, 2004).

\section{Results and discussion}

\subsection{Sources and controls of arsenic}

Results of the solid-phase As analysis of sediments form the CLBR basin are summarized in Table 3. Whole rock analyses of 216 unconsolidated sediment samples indicate that the mean As concentration was $6 \mathrm{ppm}(\min =0.3 ; \max =17)$. These As concentrations are in the range typical 
for glacial deposits (average $=9 ; \min =2 ; \max =170)($ Smedley and Kinniburgh, 2002). The mean As concentration measured from the eight Lea Park Formation marine shale samples was $17 \mathrm{ppm}(\min =8.4 ; \max =20)$. Arsenic concentrations in the glacial drift sediments are relatively constant with depth for most locations (Fig. 3), with a few exceptions, including a sharp increase in concentration within the Lea Park marine shale and elevated concentrations at a few other locations. Marine shales typically contain the highest As content in the earth's crust, following gold ores (Nordstrom, 2012). Leckie et al. (1994) found that shales from the Lea Park Formation and Upper Colorado Group that underlie the CLBR basin contained abundant pyrite.

Table 3. Total As concentrations measured in sediments from the CLBR basin, including data from Andriashek (2000), Fennell (2008) and this study. All values are in ppm and BR refers to bedrock.

\begin{tabular}{lccccc}
\hline Formation & $\mathrm{n}$ & Median & Mean & Minimum & Maximum \\
\hline Grand Center & 64 & 6.4 & 6.7 & 1.2 & 17 \\
Sand River & 4 & 3.5 & 3.4 & 2.4 & 4.1 \\
Marie Creek & 71 & 5.6 & 5.9 & 3.2 & 14 \\
Bonnyville & 67 & 7.9 & 6.9 & 1.2 & 14 \\
Muriel Lake & 10 & 1.1 & 1.0 & 0.3 & 1.6 \\
Lea Park (BR) & 6 & 18 & 17 & 8.4 & 20 \\
& & & & 0.3 & 17 \\
Total - Drift & 216 & 6.3 & 6.2 & 0.3 & 20 \\
Total - Drift + BR & 222 & 6.4 & 6.5 & & \\
\hline
\end{tabular}
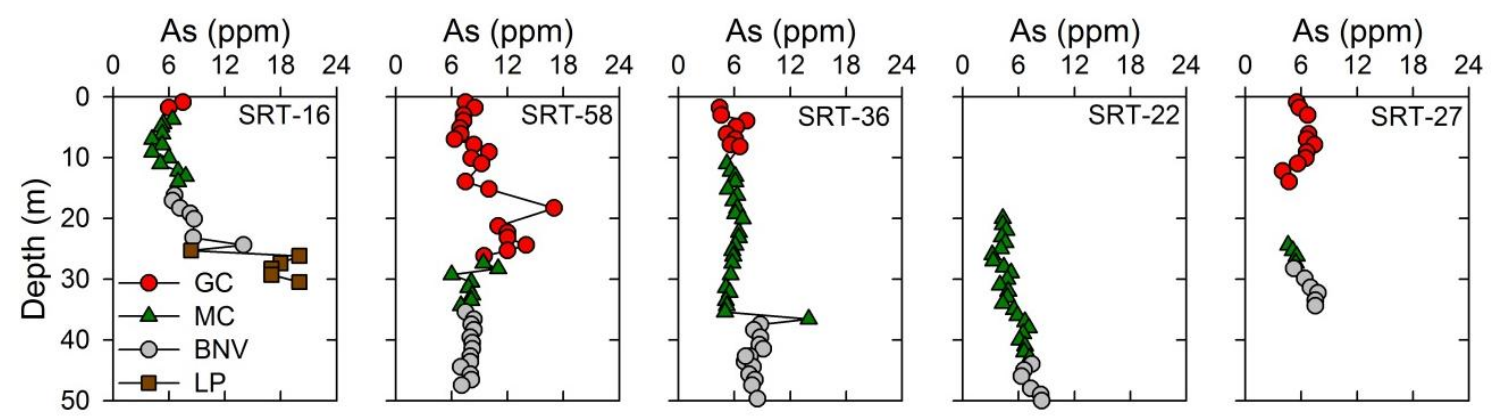

Fig. 3. Depth profile of total As concentrations from five bore-holes in the Cold Lake - Beaver River basin. GC - Grand Centre; MC - Marie Creek; BNV - Bonnyville; and LP - Lea Park Formations. Data from Andriashek (2000).

The As-bearing sediments in the CLBR basin were glacially deposited, except for the Empress 1 and 2 Formations that were deposited prior to glaciation. During four glaciation 
events, rock was eroded from the Canadian Shield, Cretaceous age marine shales and Devonian aged carbonates and transported and deposited in the CLBR basin (Andriashek and Fenton, 1989). Most of the sediments observed in CLBR basin sediments are composed of igneous and metamorphic fragments, shale and carbonates. The primary source of As within these sourcerocks is likely sulfide minerals. Marine shale from the Colorado Group, that underlies much of the CLBR basin, contained 5 to $8 \mathrm{wt} \%$ pyrite (Rokosh et al., 2009). During glaciation, these sulfide minerals would have been exposed to the atmosphere. Sulfide minerals are unstable when in contact with oxygen and will oxidize (Nordstrom, 1982). For example, the oxidation of pyrite and arsenopyrite can be expressed as:

$$
\begin{aligned}
& \mathrm{FeS}_{2}+\frac{15}{4} \mathrm{O}_{2}+\frac{7}{2} \mathrm{H}_{2} \mathrm{O} \Rightarrow \mathrm{Fe}(\mathrm{OH})_{3}+2 \mathrm{SO}_{4}{ }^{2-}+4 \mathrm{H}^{+} \\
& \mathrm{FeAsS}+3 \frac{1}{2} \mathrm{O}_{2}+4 \mathrm{H}_{2} \mathrm{O} \Rightarrow \mathrm{Fe}(\mathrm{OH})_{3}+\mathrm{SO}_{4}^{2-}+\mathrm{H}_{2} \mathrm{AsO}_{4}^{-}+3 \mathrm{H}^{+}
\end{aligned}
$$

The oxidation of pyrite (eqn.1) and arsenopyrite (eqn. 2) results in formation of secondary Feoxyhydroxide and the release of sulfate, arsenate and $\mathrm{H}^{+}$. The release of $\mathrm{H}^{+}$may reduce the porewater $\mathrm{pH}$, however sediments from the CLBR basin have a high carbonate content (Andriashek and Fenton, 1989) maintaining a circumneutral groundwater $\mathrm{pH}$ through buffering. Although not shown in equation 1, pyrite is a common carrier of As (Nordstrom, 2002; Majzlan et al., 2014) and will release arsenic during oxidation. Under circumneutral $\mathrm{pH}$ and oxidizing conditions, arsenate will adsorb to Fe-oxyhydroxide mineral phases (Dixit and Hering, 2003).

As glaciation in the CLBR basin progressed, previously deposited sediments were buried by advancing glaciation and eventually water tables within the sediments were established, limiting $\mathrm{O}_{2}$ diffusion into the sediments. In addition, the consumption of $\mathrm{O}_{2}$ by microbial oxidation of organic carbon $\left[\mathrm{CH}_{2} \mathrm{O}\right]$ will lead to anoxic conditions in the groundwater (Lovley, 
1987). Under reducing conditions, As can be released to groundwater through reductive dissolution of arseniferous Fe-oxyhydroxides. During the reductive dissolution, Fe reducing bacteria consume $\mathrm{CH}_{2} \mathrm{O}$ and utilize $\mathrm{Fe}(\mathrm{III})$-oxyhydroxide as an electron acceptor for anaerobic respiration (Hansel et al., 2003). The reduction of Fe(III)-oxyhydroxide results in the release of $\mathrm{Fe}^{2+}, \mathrm{HCO}_{3}{ }^{-}$and sorbed ions such as arsenate to the groundwater as demonstrated by Paktunc (2013) for the mobilization of arsenic as As(III) species following reductive dissolution of goethite in a tailings impoundment. Under reducing conditions, $\mathrm{As}(\mathrm{V})$ can be reduced to $\mathrm{As}(\mathrm{III})$ (Smedley and Kinniburgh, 2002; Mukherjee et al., 2012) resulting in increased concentrations and dominance of As(III) in groundwater. Arsenic reducing bacteria such as dissimilatory arsenate respiring prokaryotes catalyze organic carbon using $\mathrm{As}(\mathrm{V})$ as an electron acceptor (Zobrist, et al., 2000). The source of organic carbon in the sediments that can stimulate Fe/As reduction can be from plant material co-deposited with sediments and from DOC produced by plant or animal degradation and transported by groundwater flow. Another source of organic carbon is from glacially redeposited organic-rich shale fragments within the till matrix and thin interbedded fine grained layers within the sand and gravel. In place Colorado Group shale has a high total organic carbon (TOC) content ranging from 0.27 to $11.04 \%$, with the highest values in the Upper Colorado and Second White Specks (Tu et al., 2007). Other reactants that can promote arsenate reduction include hydrogen, hydrogen sulfide, elemental sulfur and methane (Amend et al., 2014).

In the presence of dissolved $\mathrm{SO}_{4}{ }^{2-}, \mathrm{Fe}(\mathrm{II})$ and $\mathrm{As}(\mathrm{III})$, reduction may be followed by microbially-mediated (dissimilatory) sulfate reduction (DSR) where sulfate-reducing bacteria catalyze the oxidation of $\mathrm{CH}_{2} \mathrm{O}$ reducing $\mathrm{SO}_{4}{ }^{2-}$ to $\mathrm{H}_{2} \mathrm{~S}$ (Berner, 1985). When $\mathrm{H}_{2} \mathrm{~S}$ is produced through DSR in the presence of available Fe(II) or other metals and metalloids, a secondary 
sulfide mineral will precipitate (Berner, 1985). DSR decreases the concentrations of dissolved $\mathrm{SO}_{4}{ }^{2-}, \mathrm{Fe}(\mathrm{II})$, and other elements such as $\mathrm{As}(\mathrm{III})$, and increases alkalinity and $\mathrm{pH}$ in the groundwater (Tuttle et al., 1969; Buschmann and Berg, 2009). Significant isotope fractionation of sulfur enrichment is another important indicator of DSR (Mayer, 2005).

To determine if As-bearing minerals were present in the CLBR basin, a detailed quantitative mineralogical characterization of the sediments was performed in two areas of the watershed (Fig. 1b). Both sites were located where the Grand Centre Formation outcrops and were approximately $22 \mathrm{~km}$ apart. At Site 1 a borehole was drilled to a depth of $15 \mathrm{~m}$, and at Site 2, a bore-hole was drilled to a depth of $13.5 \mathrm{~m}$. Sediments were visibly oxidized to depths of 5.8 $\mathrm{m}$ and $4.9 \mathrm{~m}$ at Sites 1 and 2, respectively. The results of the XRD analyses revealed similar mineralogical compositions in the sediments from Sites 1 and 2, with the crystalline phases consisting mainly of quartz, microcline, albite, calcic plagioclase, calcite, and amphibole, with various amounts of clay minerals such as kaolinite, montmorillonite and mica. No obvious mineralogical differences in the XRD analyses were observed between the brown oxidized and grey unoxidized sediments.

Small pyrite grains, typically framboidal in habit were found throughout the unoxidized sediment samples at Sites 1 and 2 (Fig. 4a and b). Although the pyrite does not represent a major mineral phase, it is common throughout the samples. The textural features of the framboidal pyrite grains suggest that pyrite is a neo-mineral formed within the sediments post deposition. Considering that pyrite is a common As carrier (Nordstrom, 2002), 19 BSE images of individual grains were taken and their compositions were analyzed by WDS to determine whether As was a significant compositional component. The As content of pyrite in samples was variable, reaching $1550 \mathrm{ppm}$ in a sample at Site 1, $6 \mathrm{~m}$ depth, and $1840 \mathrm{ppm}$ in a sample from Site 2 at an $11.5 \mathrm{~m}$ 
depth, with averages of 460 and 590 ppm, respectively (Table 4). The presence of As in the pyrite grains analyzed suggests that pyrite is an important As carrier in these sediment samples. None of the pyrite grains examined from the unoxidized sediments showed any evidence of oxidation features. Framboidal pyrite was not observed in the sediment samples from the oxidized zone (Site 1-1 m, and Site 2-1 m), but instead spheroidal Fe-oxyhydroxide grains with minor S and variable concentrations of As were observed (Fig. 4c and d). The habit and composition strongly suggest that these Fe-oxyhydroxide grains represent pseudomorphs after framboidal pyrite grains. The As concentrations of the characterized Fe-oxyhydroxide reached values up to $670 \mathrm{ppm}$ in Site 1-1 $\mathrm{m}$ and $2270 \mathrm{ppm}$ in Site 2-1 $\mathrm{m}$ with averages of 200 and 770 ppm, respectively (Table 4).
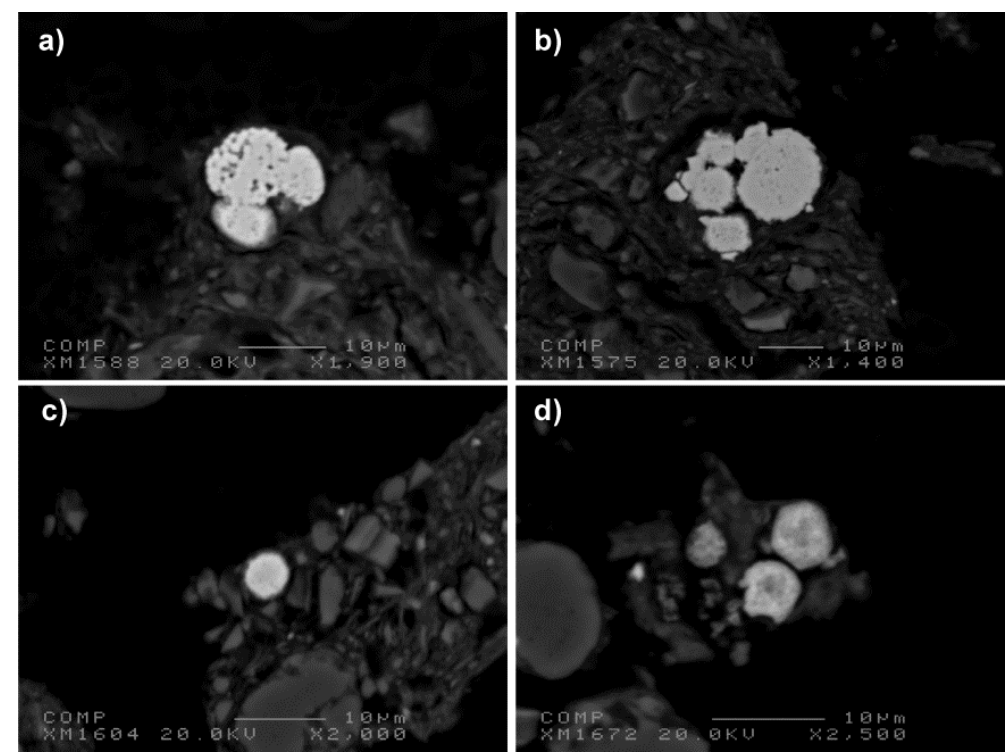

Fig. 4. BSE images of representative As-bearing mineral phases observed in sediment samples showing framboidal pyrite at; (a) Site 1, $6 \mathrm{~m}$ depth; (b) Site 2, $11.5 \mathrm{~m}$ depth. Secondary Feoxyhydroxide pseudomorphs after framboidal pyrite at; (c) Site 1, $1 \mathrm{~m}$ depth; (d) Site 2, $1 \mathrm{~m}$ depth.

Table 4. Arsenic concentration (ppm) of Fe(III)-oxyhydroxide [FeOOH] and pyrite grains in sediments from Sites 1 and 2, determined by WDS-EPMA.

\begin{tabular}{lcccc}
\hline Location & Site 1 & Site 1 & Site 2 & Site 2 \\
\hline Depth & $1 \mathrm{~m}$ & $6 \mathrm{~m}$ & $1 \mathrm{~m}$ & $11.5 \mathrm{~m}$ \\
Mineral & FeOOH & Pyrite & FeOOH & Pyrite \\
Sediment & oxidized & unoxidized & oxidized & unoxidized
\end{tabular}




\begin{tabular}{lcccc} 
Sample 1 & $<100$ & $<100$ & 2270 & $<100$ \\
Sample 2 & $<100$ & 180 & 440 & 780 \\
Sample 3 & $<100$ & 190 & 710 & 570 \\
sample 4 & 280 & 470 & 400 & 410 \\
Sample 5 & 320 & $<100$ & $<100$ & 184 \\
Sample 6 & 370 & 790 & & $<100$ \\
Sample 7 & 670 & $<100$ & & 320 \\
Sample 8 & 380 & 1550 & & \\
Sample 9 & $<100$ & 570 & & 1760 \\
Sample 10 & $<100$ & 810 & & 180 \\
\hline
\end{tabular}

K-edge XANES spectra were collected to determine the valence state (-I, III, V) in which As occurs based on the location of the absorption edges. Arsenic can occur within the structure of arsenopyrite and pyrite as As(-I), which is susceptible to oxidation particularly in the framboidal types of pyrite (Paktunc, 2008). All of the sediments with elevated concentrations of As (4.3 to $7.4 \mathrm{mg} / \mathrm{kg}$ ) had spectra with the main absorption peak centred at $11874.7 \mathrm{eV}$ (dashed line) indicating that the dominant species was As(V) (Fig. 5). The spectral features above the edge in Fig. 5 were similar to those of goethite or ferrihydrite with adsorbed As (Paktunc et al. 2004; 2008), suggesting that these Fe(III)-oxyhydroxides are the dominant As carriers in the sediments with elevated As concentrations. The sediment samples at 5.5 and $6 \mathrm{~m}$ depths along bore-hole Site 1- $1 \mathrm{~m}$ representing oxidized and unoxidized sediments displayed similar XANES spectra dominated by As(V). The spectra collected for oxidized and unoxidized sediment samples from 1 and $11.5 \mathrm{~m}$ depths along the Site 2 bore-hole displayed differences in their As Kedge. The spectrum of unweathered sample from $11.5 \mathrm{~m}$ depth had a shoulder on the lower energy side of the main absorption peak suggesting the presence of reduced As(-I) species in addition to $\mathrm{As}(\mathrm{V})$ (Fig. 5). The derivative value of this shoulder is $11868.5 \mathrm{eV}$ which is close to those of arsenopyrite and arsenian pyrite suggesting the presence of As(-I) species in addition to As(V). The presence of As(-I) species in the unoxidized portions of the sediments were consistent with the presence of sulfide minerals such as arsenian pyrite and arsenopyrite. 

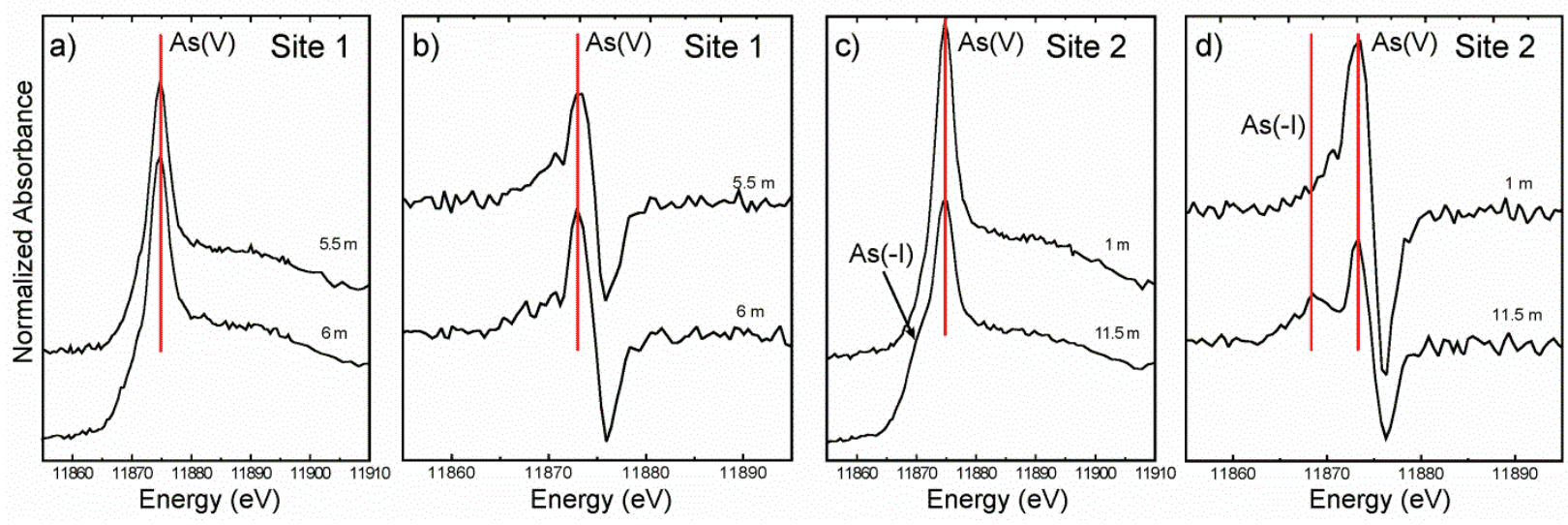

Fig. 5. Normalized As K-edge XANES spectra for sediment samples collected at; (a) Site 1, 5.5 and $6 \mathrm{~m}$ depths (c) Site 2, 1 and $11.5 \mathrm{~m}$ depths; and derivatives for samples from (b) Site 1 and (c) Site 2. Vertical line is at $11874.7 \mathrm{eV}$ representing the main absorption peak for $\mathrm{As}(\mathrm{V})$ and $11868.5 \mathrm{eV}$ in (d) representing As(-I).

Previous mineralogical analyses of sediments from the Muriel Lake Formation (Fennell, 2008) also indicated the presence of framboidal pyrite in the sediments. In this study, SEMmicroprobe analysis of the pyrite detected the presence of As, but only qualitatively at low concentrations. XANES analysis of the sediments identified $\mathrm{As}(\mathrm{V})$ as the dominant species, with minor amounts of As(III) present.

\subsection{Arsenic Distribution in Groundwater}

Understanding the distribution of As concentrations in aquifers is crucial for determining the placement of wells for extraction of potable water and health-risk studies. Arsenic concentrations in groundwater varied spatially across the CLBR basin and within individual formations, with no obvious trends observed along groundwater flowpaths (Fig 6). Overall, there were no obvious distribution patterns of As in groundwater except for an area west of Cold Lake where As concentration in some wells are elevated in all formations except the Grand Centre Formation. The heterogeneous nature of glacially deposited sediments likely influences the random distribution of As in both solid and aqueous phases within the CLBR basin. 


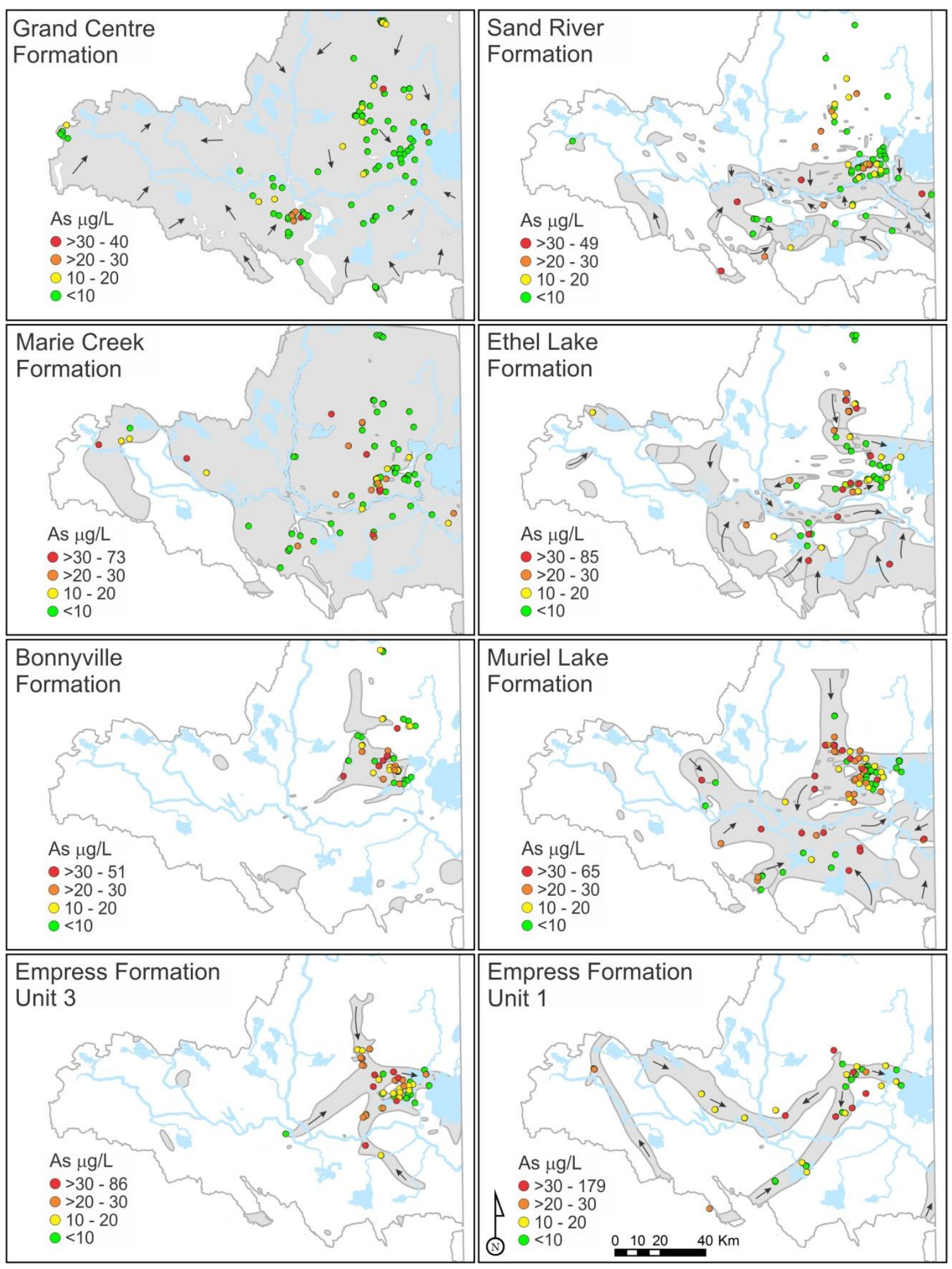

Fig. 6. Spatial distribution of As in groundwater across the CLBR Basin. Arrows show groundwater flow direction in each formation (modified after Parks et al., 2005). Grey shading indicates the extent of each formation. There was insufficient data to map groundwater flow in the Marie Creek and Bonnyville Formations. 
The mean concentration of As in all glaciofluvial formation groundwaters was $15 \mu \mathrm{g} / \mathrm{L}$, ranging between $<1$ to $179 \mu \mathrm{g} / \mathrm{L}$, with $50 \%$ of the wells exceeding $10 \mu \mathrm{g} / \mathrm{L}$ (Table 5). Arsenic concentration in groundwater were lowest in the uppermost Grand Centre Formation with only $17 \%$ of the wells exceeding $10 \mu \mathrm{g} / \mathrm{L}$, whereas concentrations were highest in the deeper Empress 3 Formation where $70 \%$ of the wells were $>10 \mu \mathrm{g} / \mathrm{L}$. There were minimal differences in As groundwater concentrations between aquitard and aquifer units. For example, average concentration of As in groundwater between the aquitard and aquifer units in the Bonnyville and Empress Formations only differed by a few micrograms per liter. In general, As concentrations in groundwater increased with depth through the unconsolidated sediments. Within the underlying shale units, all seven of the wells sampled had As concentrations that were below 10 $\mu \mathrm{g} / \mathrm{L}$. It was previously suggested that elevated As concentration in shallow Quaternary aquifers in Alberta could originate from the underlying pyritic shales (AHW, 2000; Fitzgerald et al., 2001). However the low As concentrations in groundwater from these deep shales suggest that they are not directly contributing to elevated concentrations (Table 5). Nevertheless, if these shales were exposed to oxygen by over pumping of a well or if fragments of these shales are present in near-surface sediments, arsenian sulfide minerals could oxidize releasing As to the groundwater.

Table 5. Arsenic concentrations in groundwater from formations in the CLBR Basin.

\begin{tabular}{|c|c|c|c|c|c|c|c|c|c|}
\hline \multirow{2}{*}{ Formation } & \multirow{2}{*}{$\mathrm{n}$} & \multirow{2}{*}{$\begin{array}{c}\text { Median } \\
\mu \mathrm{g} \mathrm{L}^{-1}\end{array}$} & \multirow{2}{*}{$\begin{array}{l}\text { Average } \\
\mu \mathrm{g} \mathrm{L}^{-1}\end{array}$} & \multirow{2}{*}{$\begin{array}{c}\text { Max. } \\
\mu \mathrm{g} \mathrm{L}^{-1}\end{array}$} & \multirow{2}{*}{$\begin{array}{l}\text { Min. } \\
\mu \mathrm{g} \mathrm{L}^{-1}\end{array}$} & \multirow{2}{*}{$\begin{array}{c}\text { Wells } \\
\text { Exceeding } \\
10 \mu \mathrm{g} \mathrm{L}^{-1}\end{array}$} & \multirow{2}{*}{$\begin{array}{c}\% \text { Wells } \\
\text { Exceeding } \\
10 \mu \mathrm{g} \mathrm{L}^{-1}\end{array}$} & \multicolumn{2}{|c|}{$\mathrm{As}(\mathrm{III}) / \mathrm{As}_{\mathrm{T}}$} \\
\hline & & & & & & & & (n) & $\%$ \\
\hline Grand Center & 149 & 3 & 6 & 70 & $<1$ & 23 & 17 & 23 & 46 \\
\hline Sand River & 79 & 8 & 12 & 61 & $<1$ & 32 & 41 & 27 & 66 \\
\hline Marie Creek & 101 & 8 & 11 & 160 & $<1$ & 30 & 33 & 29 & 65 \\
\hline Ethel Lake & 80 & 11 & 15 & 100 & $<1$ & 41 & 51 & 21 & 82 \\
\hline Bonnyville Unit 2 & 33 & 10 & 17 & 110 & $<1$ & 16 & 48 & 14 & 61 \\
\hline Bonnyville & 75 & 11 & 14 & 70 & $<1$ & 37 & 51 & 6 & 85 \\
\hline Bonnyville Unit 1 & 21 & 11 & 16 & 50 & 2.0 & 11 & 52 & 3 & 88 \\
\hline Muriel Lake & 133 & 17 & 19 & 140 & $<1$ & 89 & 67 & 25 & 82 \\
\hline Bronson Lake & 14 & 22 & 21 & 70 & $<1$ & 8 & 57 & 4 & 72 \\
\hline
\end{tabular}




\begin{tabular}{lccccccccc} 
Empress Unit 3 & 71 & 18 & 19 & 86 & $<1$ & 50 & 70 & 8 & 80 \\
Empress Unit 2 & 10 & 10 & 16 & 100 & 5.9 & 5 & 50 & - & - \\
Empress Unit 1 & 43 & 11 & 17 & 179 & $<1$ & 25 & 58 & 15 & 84 \\
Lea Park & 2 & 3 & 3 & 3.1 & 2.9 & 0 & 0 & - & - \\
Upper Colorado & 3 & 4 & 3.3 & 4.4 & 2.0 & 0 & 0 & - & - \\
$2^{\text {nd }}$ White Specks & 2 & - & 5 & 9 & $<1$ & 1 & 0 & - & - \\
Average Glacial & 816 & 11 & 15 & 124 & & 27 & 50 & 175 & 74 \\
\hline
\end{tabular}

Groundwater from the CLBR basin has As(III) as the principal species, accounting for $80 \%$ of the As (Table 5). Groundwater from the Grand Centre Formation had the lowest As(III) ratio making up only $46 \%$ of the As. Overall the As(III) ratio increased with depth. At depth, over $80 \%$ of the groundwater from aquifer units contained As(III), whereas groundwater from till units had lower percentages of $\mathrm{As}(\mathrm{III}) / \mathrm{As}_{\mathrm{T}}$, except for the Bonnyville Unit 1 Till. The dominance of As(III) over As(V) in groundwaters from the CLBR basin indicates a strongly reducing environment.

Arsenic concentrations within groundwater from the CLBR basin appear to be strongly influenced by redox conditions. Arsenic concentrations increased as the Eh decreased, with the highest As concentrations associated with the lowest Eh values (Fig. 7). The groundwater samples from reducing environments with elevated As concentrations tended to have lower concentrations of $\mathrm{SO}_{4}{ }^{2-}$ and $\mathrm{Fe}(\mathrm{II})$. The highest As concentrations were found in groundwater with circumneutral $\mathrm{pH}$ conditions and with alkalinities at approximately $600 \mathrm{mg} / \mathrm{L} \mathrm{CaCO}_{3}$. The average DOC concentrations in the groundwaters across the CLBR basin was $3.1 \mathrm{mg} / \mathrm{L}$, but the highest As concentrations were found in groundwaters with about $5 \mathrm{mg} / \mathrm{L}$ of DOC. These average groundwater DOC concentrations are not particularly high, but even at low concentrations, OC $(\leq 1 \%)$ in the sediments can promote microbially mediated reduction reactions (Héry et al., 2010). Geochemical modelling calculations indicated that $72 \%$ of groundwater from the wells were at equilibrium or undersaturated with respect to ferrihydrite (Fig. 7). These calculations suggest that the primary mechanism for As release from the 
sediments is the reductive dissolution of Fe-oxyhydroxides. In addition to the release of As, elevated concentrations of $\mathrm{Fe}$ would be expected during reductive dissolution of $\mathrm{Fe}$ oxyhydroxides provided that the dissolution is congruent and the Fe species remains in solution. The correlation between As and Fe concentrations in the groundwater were not strong, except for the Bronson Lake Formation $\left(\mathrm{R}^{2}=0.71\right)$. All other As to Fe relations had a $\mathrm{R}^{2}<0.26$. This poor correlation between As and $\mathrm{Fe}$ may be due to scavenging of Fe during siderite $\left[\mathrm{FeCO}_{3}\right]$ precipitation. Speciation model calculations found that $80 \%$ of groundwater for the wells was at equilibrium or supersaturated with respect to siderite. Siderite is below the XRD detection limit of several percent. If present, it would be in trace quantities in the sediment. Siderite precipitation will remove $\mathrm{Fe}$ (II) from solution and is known to be an effective sink for As in groundwater (Mumford et al., 2012), sorbing both As(III) and As(V) (Islam et al., 2005), with the sorption of As(III) being the weaker of the two oxidation states (Jönsson and Sherman, 2008). Ferric-oxyhydroxide phases were not identified in the unoxidized sediments during the mineralogical study, yet XANES experiments revealed that over $75 \%$ of the solid-phase As concentrations in the sediments was As(V), similar to observations by Javed et al. (2014) that observed 25 to $75 \%$ of As in other areas of the CLBR basin sediments was bound in oxides. In other aquifers with elevated groundwater As concentrations, reductive dissolution of Feoxyhydroxides has been proposed as the principal process for As release from alluvial and glacofluvial sediments, for example in Southeast Asia (Nickson et al., 2000; Fendorf et al., 2010), USA Midwest (Kelly et al., 2005; Erickson and Barns, 2005), China (Guo et al., 2013) and Alaska (Munk et al., 2011). Although the groundwater chemistry, speciation modeling and mineralogy all are consistent with the prevalence of reductive dissolution of Fe-oxyhydroxides in deeper sediments from the CLBR basin, competitive desorption by phosphate or silica (Manning 
and Goldberg, 1996; Holm, 2002) or desorption from clay minerals cannot be ruled out as additional processes that may be contributing to As release to groundwater.
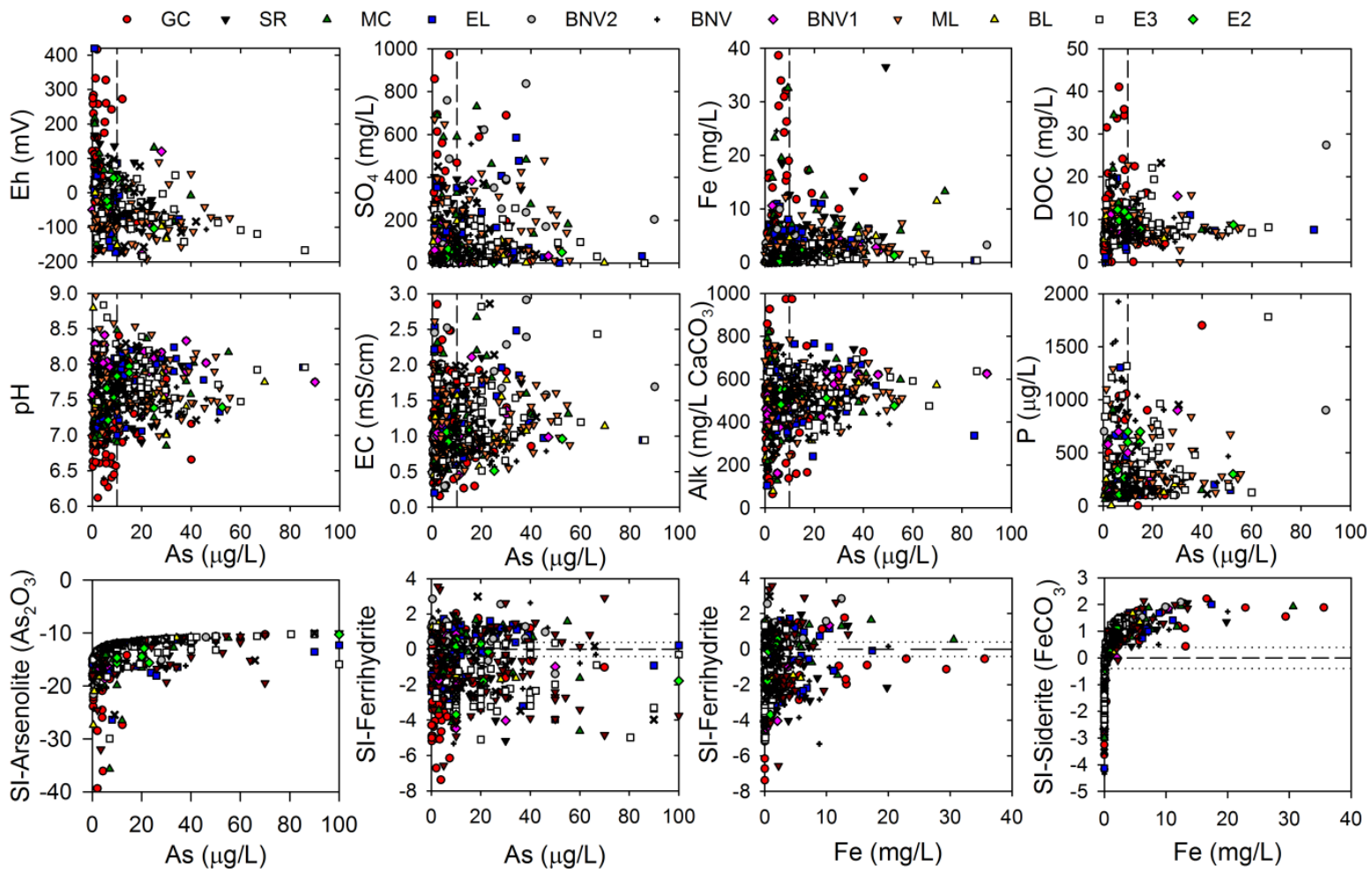

Fig. 7. The relationship between As concentrations in groundwater and various other aqueous parameters (top two rows). Plots in the bottom row show calculated SI values for arsenolite, ferrihydrite and siderite (near equilibrium conditions $\mathrm{SI}=-0.4$ to 0.4 , are represented by the horizontal dashed lines). Symbols are representative of the different formations included in the dataset.

There are general trends in $\mathrm{pH}$ and Eh conditions related to depth and geological formation (Fig. 8). The most oxidizing conditions (Eh and DO) were observed at shallow depths, in the near surface zone of the Grand Centre and Sand River Formations. Groundwater from the Grand Centre Formation had the lowest $\mathrm{pH}$ values which corresponded to the highest concentrations of $\mathrm{F}, \mathrm{Cl}, \mathrm{Si}$ and $\mathrm{Ca}, \mathrm{Mg}, \mathrm{U}$, and $\mathrm{Fe}$. Chemical weathering occurring in the surficial sediments is likely releasing elevated concentrations of ions to the pore water which is displaced downward into shallow groundwater, which is consistent with the mineralogical analyses of the 
near-surface Grand Centre Formation sediments that showed visibly oxidized sediments and the complete consumption of sulfide minerals in the weathered zones. Groundwater sampled from 1 $\mathrm{m}$ below the oxidized zone in the Grand Centre Formation contained a depressed $\mathrm{pH}$ and elevated concentrations of major ions in the groundwater. In addition to elevated major anions and cations, elevated concentrations of $\mathrm{NO}_{3}{ }^{-}$and $\mathrm{DOC}$ were present in the shallow groundwater (Fig. 8). The elevated concentrations of $\mathrm{NO}_{3}{ }^{-}$and DOC are likely from anthropogenic sources such as the application of fertilizers, feed lots, and sewage seepage from septic tanks and lagoons. Elevated DOC was also observed in deeper groundwater $>100 \mathrm{~m}$ depth (Figure 8). The source of DOC at depth is likely organic-rich shale that is dispersed throughout the unconsolidated sediments. 

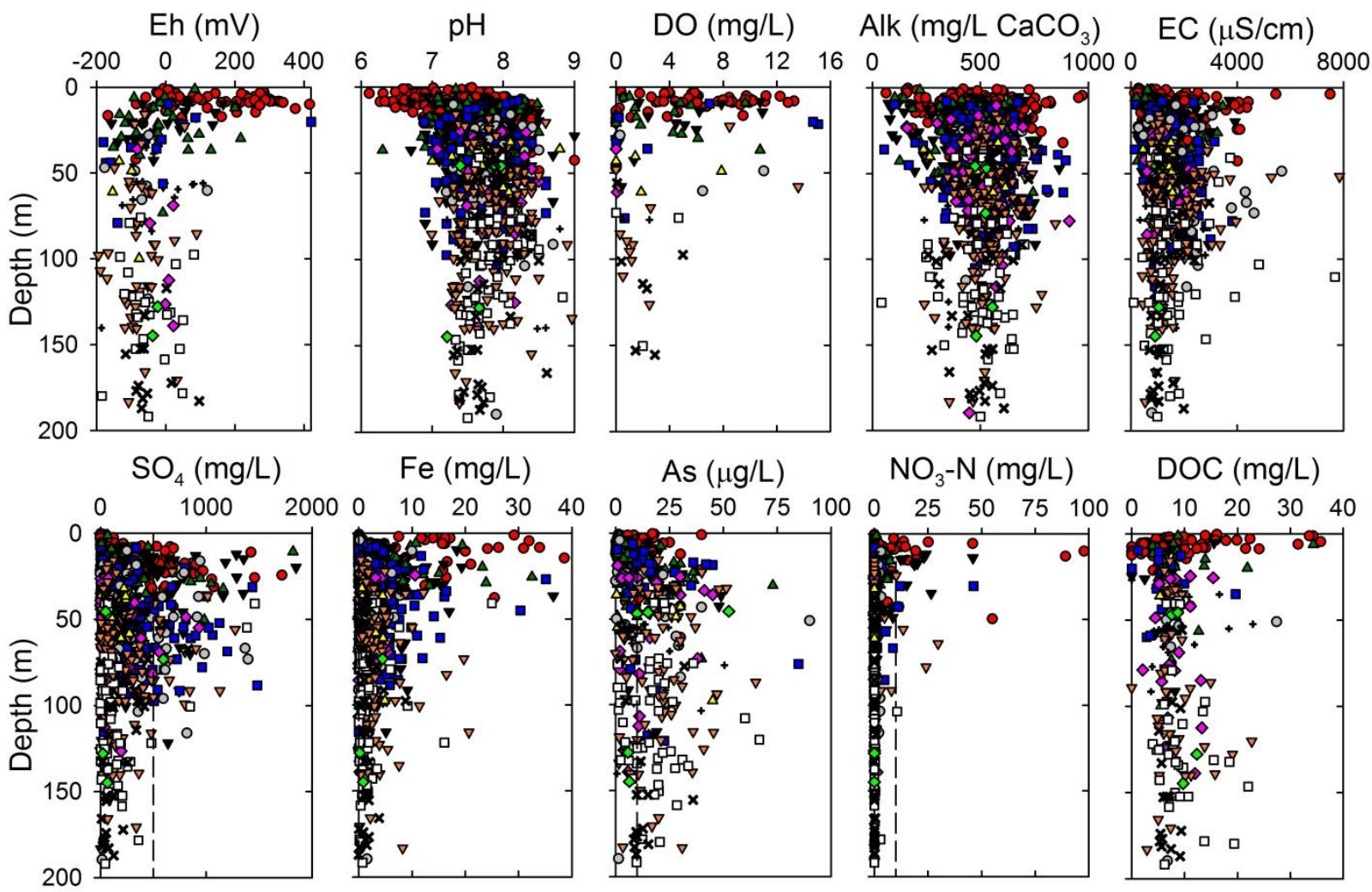

$\mathrm{Fe}(\mathrm{mg} / \mathrm{L})$

As $(\mu \mathrm{g} / \mathrm{L})$

$\mathrm{NO}_{3}-\mathrm{N}(\mathrm{mg} / \mathrm{L})$
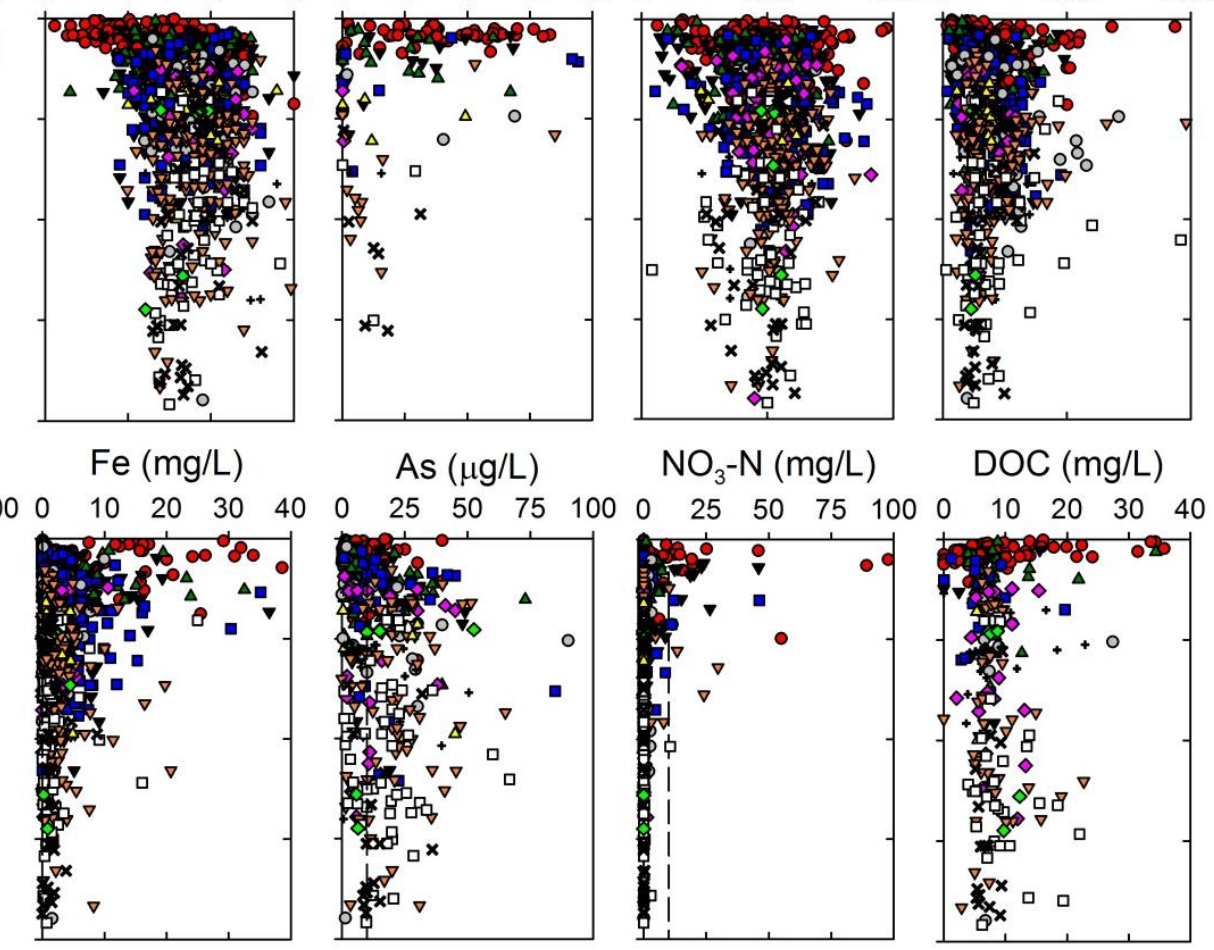

$\mathrm{DOC}(\mathrm{mg} / \mathrm{L})$
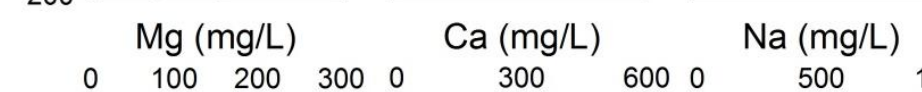

$\mathrm{K}(\mathrm{mg} / \mathrm{L})$
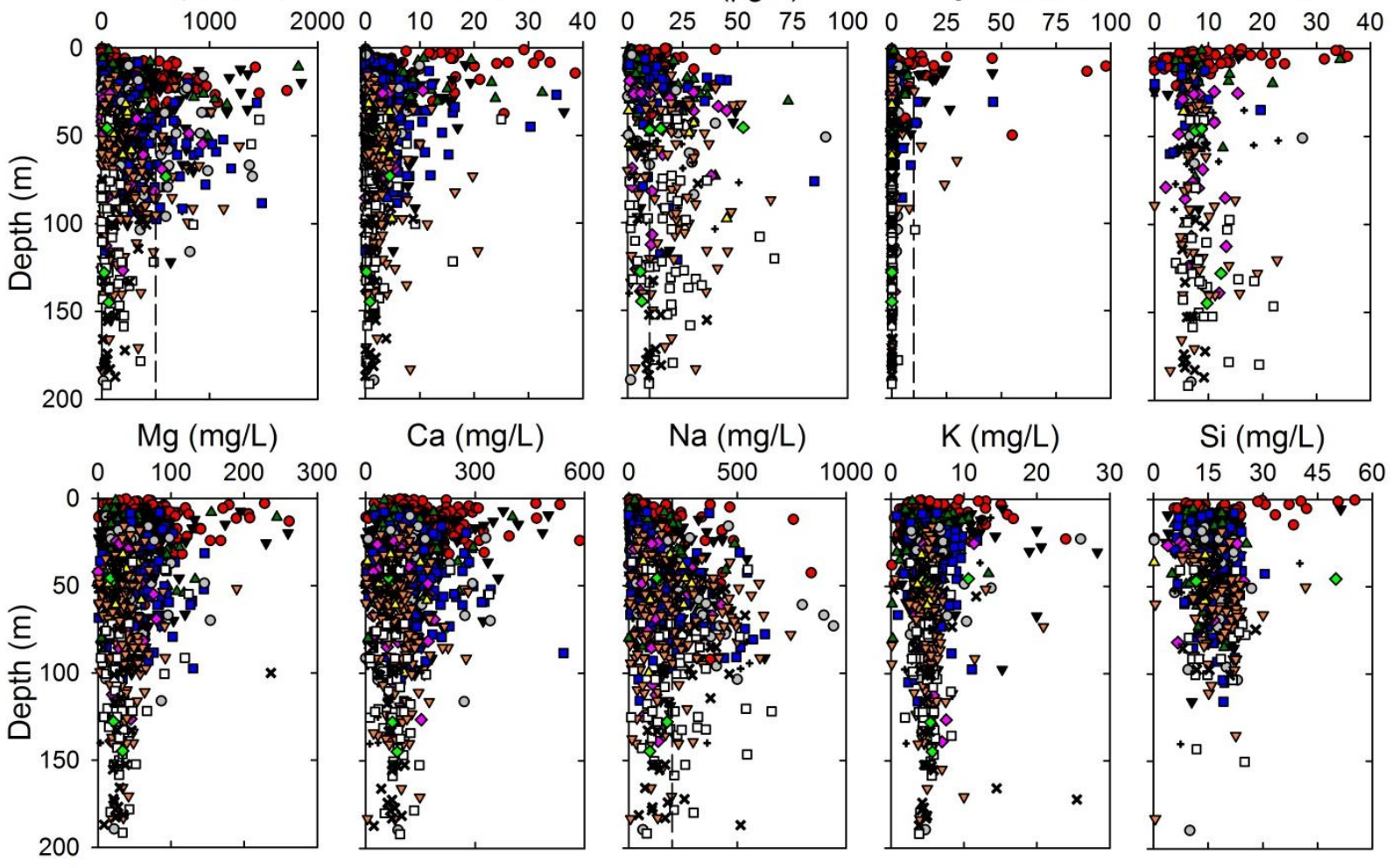

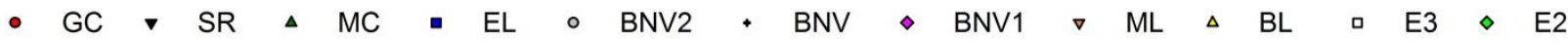

Fig. 8. Depth profiles of groundwater chemistry from the CLBR basin. The vertical dashed lines represent maximum allowable drinking water limits.

In addition to biogeochemical redox reactions that release As from sediments,

hydrogeologic properties of the aquifer material will influence groundwater flow and residence time, affecting As concentrations (Smedley and Kinniburgh, 2002). The ${ }^{14} \mathrm{C}$ and ${ }^{3} \mathrm{H}$ data indicate the Grand Center and Marie Creek Formations have the youngest groundwater ages (Table 6). Tritium was not detected in any of the samples from the Ethel Lake Formation or deeper, 
indicating no evidence of post 1950's water in these samples. There was a wide range in ${ }^{14} \mathrm{C}$ ages for some of the formations, but in general groundwater ages increase with depth. The large range in ages in some formations (e.g. Empress Unit 1) are not surprising since the well locations are located along a flow path, and the oldest ages are associated with the more distal reaches of the formation. These long residence times of groundwater flow in the aquifers can influence As mobilization. For example, the average As concentration in groundwater from the Grand Centre Formation was $6 \mu \mathrm{g} \mathrm{L}^{-1}$ with modern aged water signifying a short groundwater flow path and residence time. Conversely, the average As concentration in the Empress Unit 1 was $17 \mu \mathrm{g} \mathrm{L}^{-1}$ with groundwater ages ranging between 25,000 to 3000 years before present, indicating a long groundwater flow path and residence time. The long groundwater flow path and residence time can allow As to accumulate in the groundwater to where concentrations become hazardous (Barringer and Reilly, 2013).

Table 6. Stable isotope and radiocarbon data from groundwater in the CLBR basin. NETPATH was used to correct groundwater ages. Number of wells sampled is represented by n. VCDT refers to Vienna Canyon Diablo Troilite.

\begin{tabular}{|c|c|c|c|c|c|c|c|}
\hline Formation & \multicolumn{4}{|c|}{ Carbon } & \multirow{2}{*}{$\begin{array}{c}\text { Tritium } \\
\text { (T.U.) }\end{array}$} & \multicolumn{2}{|c|}{ Sulfur } \\
\hline & $\mathrm{n}$ & $\begin{array}{c}\delta^{13} \mathrm{C}_{\mathrm{DIC}} \\
(\% \mathrm{VPDB})\end{array}$ & $\begin{array}{l}{ }^{14} \mathrm{C}_{\text {DIC }} \\
\text { pMC }\end{array}$ & $\begin{array}{c}\text { Corr. Age } \\
\text { (years B.P.) }\end{array}$ & & $\mathrm{n}$ & $\begin{array}{c}\delta^{34} \mathrm{~S}_{-} \mathrm{SO}_{4} \\
(\% \text { VCDT })\end{array}$ \\
\hline Grand Center & 1 & -15.2 & 78.6 & Recent & 10.2 & 2 & -5.8 \\
\hline Sand River & & - & - & - & - & 1 & -0.2 \\
\hline Marie Creek & 2 & -15.2 to -14.0 & $50.9-99$ & 1700 - recent & $<0.8-14.4$ & 2 & $\begin{array}{l}-1.1 \\
\end{array}$ \\
\hline Ethel Lake & 4 & -14.9 to -16.1 & $31.5-61.2$ & $6200-1200$ & $<0.8$ & 2 & -4.4 \\
\hline Bonnyville & 1 & -13.2 & 54.6 & 3700 & $<0.8$ & 1 & -6.2 \\
\hline Muriel Lake & 3 & -20.1 to -6.8 & $18.1-59.6$ & $14000-800$ & $<0.8$ & 3 & +0.2 \\
\hline Bronson Lake & & - & - & - & - & 1 & -7.9 \\
\hline Empress Unit 3 & 2 & -18.7 to -15.2 & $9.9-28.5$ & $18000-6700$ & $<0.8$ & 4 & +19.5 \\
\hline Empress Unit 1 & 7 & -22.7 to -13.3 & $5.5-42.4$ & $25000-3000$ & $<0.8$ & 8 & -0.7 \\
\hline
\end{tabular}

Sulfur isotope ratio determinations on the $\mathrm{SO}_{4}{ }^{2-}$ ion is a valuable tool for determining sources of dissolved $\mathrm{SO}_{4}{ }^{2-}$ in groundwater. Typical values of $\delta^{34} \mathrm{~S}^{-\mathrm{SO}_{4}}$ derived from sulfide oxidation range between -30 to $+10 \%$ (Mayer, 2005). With the exception of the data from the 
Empress Unit 3 Formation, the $\delta^{34} \mathrm{~S}_{-} \mathrm{SO}_{4}$ results for the other formations are consistent with $\mathrm{SO}_{4}{ }^{2-}$ originating from the oxidation of pyrite (Table 6). The depleted isotopic composition of groundwater from the formations suggests the oxidation of sulfides during recharge and glaciation contributed to $\mathrm{SO}_{4}{ }^{2-}$ concentrations and that earlier redox conditions in the formations were potentially oxic. Within the Empress Unit 3 Formation, the $\delta^{34} \mathrm{~S}^{\mathrm{SO}} \mathrm{S}_{4}$ value in groundwater near the recharge zone was $+13.8 \%$, with $\mathrm{SO}_{4}{ }^{2-}$ and As concentrations of $42 \mathrm{mg} \mathrm{L}^{-1}$ and $24 \mu \mathrm{g}$ $\mathrm{L}^{-1}$, respectively. Further down-gradient along the flow-path, $\delta^{34} \mathrm{~S}^{-\mathrm{SO}_{4}}$ showed significant enrichment to $+36.2 \%$ corresponding to decreased concentrations of $\mathrm{SO}_{4}{ }^{2-}$ and As of $1.3 \mathrm{mg} \mathrm{L}$ ${ }^{1}$ and $9.6 \mu \mathrm{g} \mathrm{L}^{-1}$, respectively, suggesting that DSR is occurring in the Empress Unit 3 formation and potentially limiting As concentrations in groundwater.

\subsection{Long-term arsenic variations}

Long-term variability of As concentrations in groundwater were evaluated using data from repeat sampling of groundwater wells between 2001 and 2009 (Fig. 9). The database included timeseries data for seven of the eight formations, with only data from the Bronson Lake Formation not available. The temporal variations in As concentrations in the formations were minimal, similar to what has been reported in other temporal studies (Ayotte et al., 2014). These small variations were observed in all formations. The largest variations of As were observed in the Ethel Lake and Empress Formations, although there did not appear to be any correlation in trends between the aquifers. There also did not appear to be strong seasonal variations in any of the formations as other studies have observed in groundwater from Vietnam (Berg et al., 2001), Bangladesh (Cheng, et al., 2005), Mongolia (Guo, et al., 2013) and the United States (Ayotte et al., 2014). The shallower wells (Sand River and Ethel Lake) showed slight increases in As concentrations, whereas the deeper wells (Bonnyville, Muriel Lake, Empress) exhibited slight 
decreases. Long-term trends in As concentrations could not be determined for the Grand Centre or Marie Creek wells due to their limited $<3$ year dataset (Ravenscroft et al., 2006). It is reasonable to conclude that natural As concentrations in the groundwater from formations in the CLBR basin are not significantly variable over the long-term. However for wells where As concentration are near maximum drinking water guidelines, the variability of As concentrations in the groundwater could be large enough to be a potential long-term risk to human health.
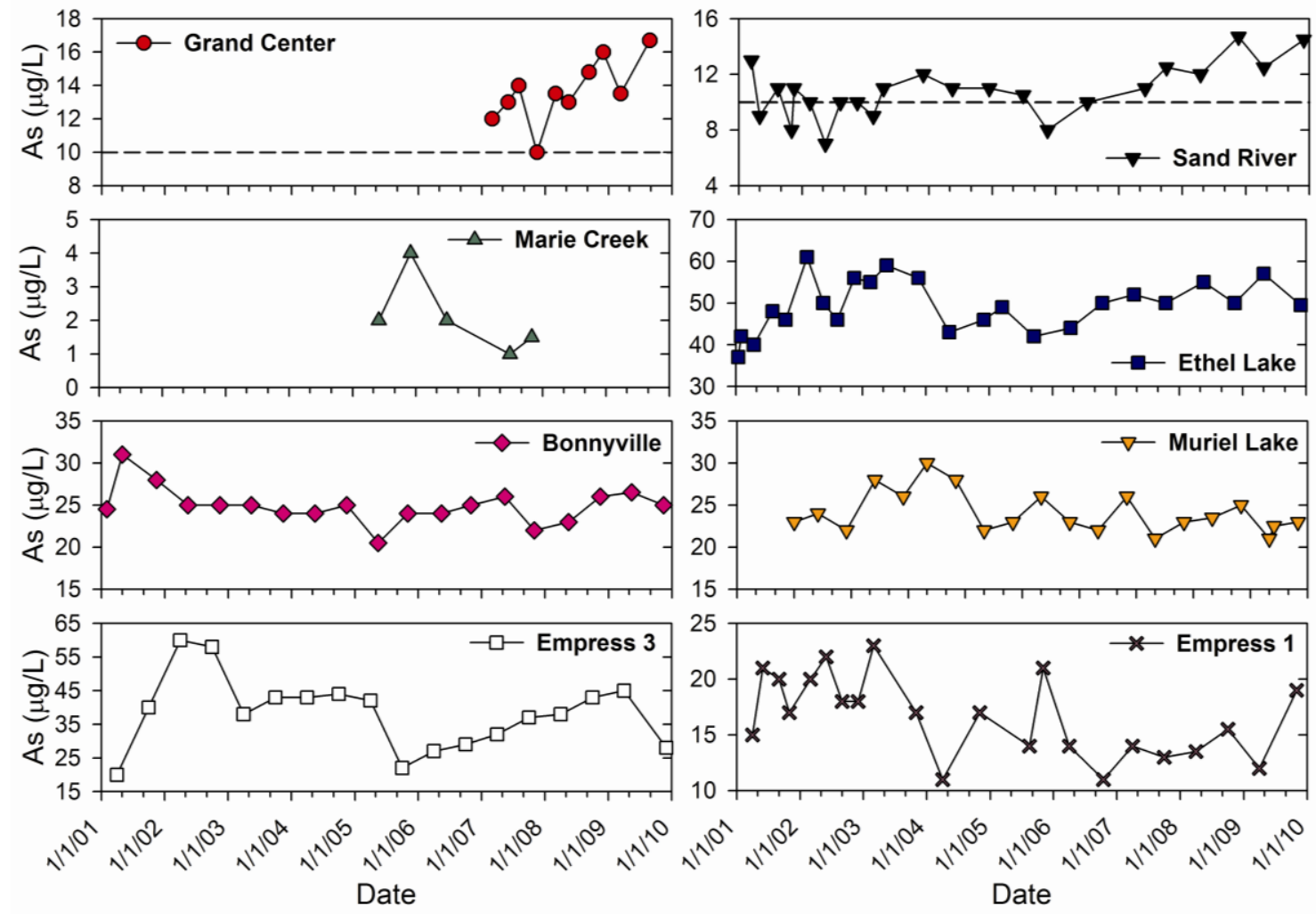

Fig. 9. Temporal variation of As concentrations in groundwater from wells in eight aquifers within the CLBR basin between 2000 and 2010. Horizontal dashed line represents the As drinking water standard of $10 \mu \mathrm{g} / \mathrm{L}$

\section{Conclusions}

Glacialfluvial aquifers of the CLBR basin contained widespread elevated arsenic concentration in groundwater with $50 \%$ of the wells exceeding $10 \mu \mathrm{g} / \mathrm{L}$. The distribution of As did not show 
any obvious spatial patterns or trends along groundwater flow paths. Arsenic concentrations measured from groundwater in the underlying marine shale was $<10 \mu \mathrm{g} / \mathrm{L}$. Speciation of the arsenic found that arsenite, the more mobile and toxic form was dominant in most of the groundwater. The highest concentrations of As was associated with reducing conditions, circumneutral $\mathrm{pH}$ and lower concentrations of $\mathrm{Fe}$ and $\mathrm{SO}_{4}{ }^{2-}$. Speciation modeling showed that the majority of groundwater samples were undersaturated with respect to ferrihydrite. These relations suggested that reductive dissolution of Fe-oxyhydroxides may be the source of some of the As in the groundwater.

Arsenic concentrations in glacialfluvial sediment from the CLBR basin ranged from 1 to $17 \mathrm{ppm}$, with an average of $6 \mathrm{ppm}$. Mineralogical characterization of sediment samples revealed the presence of unoxidized framboidal pyrite in the deeper sediments with an average As concentration of $530 \mathrm{ppm}$, reaching up to $1840 \mathrm{ppm}$. In contrast, the near surface oxidized sediments did not contain framboidal pyrite, but exhibited spheroidal Fe-oxyhydroxide with elevated As concentrations, interpreted to be an alteration product of former framboidal pyrite grains. XANES indicated that the oxidized sediments are dominated by As(V) species having spectral features similar to those of goethite or ferrihydrite with adsorbed As, suggesting that Feoxyhydroxides are the dominant As carriers. In constrat XANES spectra collected on unoxidized sediment samples indicated the presence of a reduced As species (As(-I)) characteristic of arsenopyrite and arsenian pyrite. Ferric-oxyhydroxide phases were not identified in the unoxidized sediments during the mineralogical study, however XANES experiments revealed that over $75 \%$ of the solid-phase As concentrations in the sediments was As(V) suggesting that Fe reduction of Fe-oxyhydroxides could be the main source of As to the groundwater, consistent with modeling results. Within the near-surface sediments, mineralogical analyses indicate that 
the oxidation of frambroidal pyrite during weathering may be the source of As released to shallow aquifers in this region. Understanding the distribution and form of As present naturally in aquifer material and groundwater in the CLBR is important for managing water resources in the region, including the location of domestic water wells to minimize the potential health risks of As exposure.

\section{Acknowledgments}

Funding for this project was provided by Alberta Health and Wellness, Alberta Environment, Beaver River Watershed Alliance and Alberta Innovates - Technology Futures. We thank Joe Prusak, Debora Mooney, Don Jones, Kent Richardson and Laurence Andriashek for their technical assistance. The authors greatly appreciate land owners who allowed us access to their water wells and the collection of sediments on their property. The XAFS experiments were performed at the PNC/XOR beamline, Advanced Photon Source, Argonne National Laboratory which is supported by the US Department of Energy under Contracts W-31-109-Eng-38 (APS) and DE-FG03-97ER45628 (PNC-CAT). The XAFS experiments were also supported by the Natural Sciences and Engineering Research Council of Canada through a MRS grant. This manuscript benefited from critical reviews by Kate Campbell and two anonymous reviewers.

\section{References}

AESRD (Alberta Environment and Sustainable Resource Development), 2013. Lower Athabasca region groundwater management framework: supporting document for the Cold Lake Beaver River (CLBR) area. ISBN: 978-1-4601-1117-8.

AHW (Alberta Health and Wellness), 2000. Arsenic in groundwater from domestic wells in three areas of northern Alberta. Health Surveillance Report, ISBN (0-7785-0708-4).

AHW (Alberta Health and Wellness), 2014. Domestic well water quality in the Beaver River Basin 2009, drinking water quality and human health assessment. Alberta Domestic Well Water Quality and Assessment Program. ISBN (978-0-7785-8281-6). 
Amend, J.P., Saltikov, C., Lu, G.S., Hernandez, J., 2014. Mirobial arsenic metabolism and reaction energetics. In: Bowell, R.J., Alpers, C.N., Jamieson, H.E., Nordstrom, D.K., Majzlan, J., (Eds.), Arsenic: Environmental Geochemistry, Mineralogy, and Microbiology. Rev. Mineral. Geochem. 79, 391-433.

Anawar, H.M., Akai, J., Komaki, K., Terao, H., Yoshioka, T., Ishizuka, T., 2003. Geochemical occurrence of arsenic in groundwater of Bangladesh: sources and mobilization. J. Geochem. Explor. 77, 109-131.

Andrade, C.F., Jamieson, H.E., Kyser, T.K., Praharaj, T., Fortin, D., 2010. Biogeochemical redox cycling of arsenic in mine-impacted lake sediments and co-existing pore waters near Giant Mine, Yellowknife Bay, Canada. Appl. Geochem. 25, 199-211.

Andriashek, L.D., Fenton, M.M., 1989. Quaternary Stratigraphy and Surficial Geology of the Sand River Area. Alberta Research Council, NTS 73L, Bulletin 57.

Andriashek, L.D., 2000. Geochemistry of Selected Glacial and Bedrock Geologic Units, Cold Lake Area, Alberta. Alberta Geological Survey Earth Sciences Report 2000-10.

Andriashek, L.D., 2003. Quaternary Geological Setting of the Athabasca Oil Sands (In Situ) Area, Northeast Alberta. Alberta Geological Survey Earth Sciences Report 2002-03.

Ayotte, J.D., Belaval, M., Olson, S.A., Burow, K.R., Flanagan, S.M., Hinkle, S.R., Lindsey, B.D., 2014. Factors affecting temporal variability of arsenic in groundwater used for drinking water supply in the United States. Sci. Tot. Environ. DOI:

10.1016/j.scitotenv.2014.02.057.

Ball, J.W., Nordstrom, D.K., 1991. User's manual for WATEQ4F with revised thermodynamic data base and test cases for calculating speciation of major, trace and redox elements in natural waters. U.S. Geol. Surv. Open-File Rep. 91-183.

Barringer, J.L., Reilly, P.A., 2013. Arsenic in groundwater: a summary of sources and the biogeochemical and hydrogeologic factors affecting arsenic occurrence and mobility, Chapter 4. In: Bradley, P.M. (Ed.) Current Perspectives in Contaminant Hydrology and Water Resources Sustainability. DOI: 10.5772/55354.

Berg, M., Tran, H.C., Nguyen, T.C., Pham, H.V., Schertenleib, R., Giger, W., 2001. Arsenic contamination of groundwater and drinking water in Vietnam: a human health threat. Environ. Sci. Technol. 35, 2621-2626.

Berner, R.A., 1985. Sedimentary pyrite formation: an update. Geochim. Cosmochim. Acta 48, 605-615.

Bhandari, N., Reeder, R.J., Strongin, D.R., 2011. Photoinduced oxidation of arsenite to arsenate on ferrihydrite. Environ. Sci. Technol. 45, 2783-2789. 
Bolton, M., Beckie, R., 2011. Aqueous and mineralogical analysis of arsenic in the reduced, circumneutral groundwater and sediments of the lower Fraser River delta, British Columbia, Canada. Appl. Geochem. 26, 458-469.

Bottomley, D.J., 1984. Origins of some arseniferous groundwaters in Nova Scotia and New Brunswick, Canada. J. Hydrol. 69, 223-257.

Boyle, D.R., Turner, R.J.W., Hall, G.E.M., 1998. Anomalous arsenic concentrations in groundwaters of an island community, Bowen Island, British Columbia. Environ. Geochem. Health, 20, 199-212.

Buschmann, J., Berg, M., 2009. Impact of sulfate reduction on the scale of arsenic contamination in groundwater of the Mekong, Bengal and Red River deltas. Appl. Geochem. 24, 12781286.

Campbell, K.M., Nordstrom, D.K., 2014. Arsenic speciation and sorption in natural environments. In: Bowell, R.J., Alpers, C.N., Jamieson, H.E., Nordstrom, D.K., Majzlan, J., (Eds.), Arsenic: Environmental Geochemistry, Mineralogy, and Microbiology. Rev. Mineral. Geochem. 79, 185-216.

CNLR (Canadian Natural Resources Ltd.), 2005. Z8 Pad Arsenic Mobility Investigation, Progress Report.

Carmichael, V., Clarkson, L., 1995. Well water survey for arsenic in the Powell River and Sunshine Coast communities of British Columbia - March to June 1994. Report prepared for Coast Garibaldi Health Unit.

Cavalcanti de Albuquerque, R., Kirste, D., 2012. Arsenic mobilization in a freshening groundwater system formed within glaciomarine deposits. Appl. Geochem. 27, 21732186.

Cheng, Z., Van Geen, A., Seddique, A.A., Ahmed, K.M., 2005. Limited temporal variability of arsenic concentrations in 20 wells monitored for 3 years in Araihazar, Bangladesh. Environ. Sci. Technol. 39, 4759-4766.

Cheung, K., Sanei, H., Klassen, P., Mayer, B, Goodarzi, F., 2009. Produced fluids and shallow groundwater in coalbed methane $(\mathrm{CBM})$ producing regions of Alberta, Canada: Trace element and rare earth element geochemistry. Int. J. Coal Geol. 77, 338-349.

Dayton \& Knight. 2010. Carcross Water System Upgrades. Feasibility Assessment and Conceptual Options Report. Prepared for Yukon Government Community Services. 
Desbarats, A.J., Parsons, M.B., Percival, J.B., 2014. Arsenic mobility in mildly alkaline drainage from an orogenic lode gold deposit, Bralorne mine, British Columbia. Appl. Geochem. http://dx.doi.org/10.1016/j.apgeochem.2014.11.015.

Dixit, S., Hering, J.G., 2003. Comparison of arsenic(V) and arsenic(III) sorption onto iron oxide minerals: implications for arsenic mobility. Environ. Sci. Technol. 37, 4182-4189.

Erickson, M.L., Barnes, R.J., 2005. Glacial sediments causing regional-scale elevated arsenic in drinking water. Groundwater 43, 796-805.

Fendorf, S., Michael, H.A., van Geen, A., 2010. Spatial and temporal variations of groundwater arsenic in South and Southeast Asia. Sci. 328, 1123-1127.

Fennell, J. W., 2008. Effects of aquifer heating on groundwater chemistry with a review of arsenic and its mobility. Ph.D. Thesis, University of Calgary, Calgary, AB, pp. 330.

Ficklin, W.H. 1983. Separation of arsenic (III) and arsenic(V) in ground waters by ion exchange. Talanta, 30, 371-373.

Fitzgerald, D., Chanasyk, D.S., Neilson,R.D., Kiely, D., Audette, R., 2001. Farm Well Water Quality in Alberta. Water Qual. Res. J. Can. 36, 565-588.

Gong, Z., Lu, X., Watt, C., Wen, B., He, B., Mumford, J., Ning, Z., Xia, Y., Le, X.C., 2006. Speciation analysis of arsenic in groundwater from Inner Mongolia with an emphasis on acid-leachable particulate arsenic. Anal. Chim. Acta 555, 181-187.

Guo, H., Zhang, Y., Jia, Y., Zhao, K., Kim, K., 2013. Spatial and temporal evolutions of groundwater arsenic approximately along the flow path in the Hetao basin, Inner Mongolia. Chin. Sci. Bull. 58, 3070-3079.

Kelly, W.R., Holms, T.R., Wilson, S.D., Roadcap, G.S. 2005. Arsenic in glacial aquifers: sources and geochemical controls. Ground Water 43, 500-510.

Koch, I., Feldmann, J., Wang, L., Andrewes, P., Reimer, K.J., Cullen, W.R., 1999. Arsenic in the Meager Creek hot springs environment, British Columbia, Canada. Sci. Tot. Environ., 236, 101-117.

Korte, M.E., Fernando, Q., 1991. A review of arsenic (III) in groundwater. Critical Rev. Environ. Control 21, 1-39.

Hansel, C.M., Benner, S.G., Neiss, J., Dohnalkova, A., Kukkadapu, R.K., Fendorf, S., 2003. Secondary mineralization pathways induced by dissimilatory iron reduction of ferrihydrite under advective flow. Geochim. Cosmochim. Acta 67, 2977-2992. 
Harvey, C.F., Ashfaque, K.N., Yu, W., Badruzzaman, A.B.M., Ali, M.A., Oates, P.H., Michael, H.A., Neumann, R.B., Beckie, R., Islam, S., Ahmed, M.F., 2006. Groundwater dynamics and arsenic contamination in Bangladesh. Chem Geol. 228, 112-136.

Health Canada, 2006. Guidelines for Canadian drinking water quality: guideline technical document - arsenic. Water Quality and Health Bureau, Healthy Environments and Consumer Safety Branch, Health Canada, Ottawa, ON.

Health Canada, 2012. Guidelines for Canadian Drinking Water Quality-Summary Table. Water, Air and Climate Change Bureau, Healthy Environments and Consumer Safety Branch, Health Canada, Ottawa, ON.

Héry, M., Van Dongen, B.E., Gill, F., Mondal, D., Vaughan, D.J., Pancost, R.D., Polya, D.A., Lloyd, J.R., 2010. Arsenic release and attenuation in low organic carbon aquifer sediments from West Bengal. Geobiol. 8, 155-168.

Holm, T. R., 2002. Effects of carbonate/bicarbonate, silica, and phosphate on arsenic sorption to hydrous ferric oxide. J. Am. Water Works Assoc. 94, 174-181.

Islam, F.S., Pederick, R.L., Gault, A.G., Adams, L.K., Polya, D.A., Charnock, J.M., Lloyd, J.R., 2005. Interactions between the Fe(III)-reducing bacterium Geobacter sulfurreducens and arsenate, and capture of the metalloid by biogenic Fe(II). Appl. Environ. Microbiol. 71, 8642-8648.

Javed, M.B., Kachanoski, G., Siddique, T., 2014. Arsenic fractionation and mineralogical characterization of sediments in the Cold Lake area of Alberta, Canada. Sci. Tot. Environ. 500-501, 181-190.

Johnston, R., Heijnen, H., Wurzel, P., 2001. Safe Water Technology, Chapter 6. In: United Nations Synthesis Report on Arsenic in Drinking Water, World Health Organisation.

Jönsson, J., Sherman, D.M. 2008. Sorption of As(III) and As(V) to siderite, green rust (fougerite) and magnetite: implications for arsenic release in anoxic groundwaters. Chem. Geol. 255, 173-181.

Jung, H.B., Bostick, B.C., Zheng, Y., 2012. Field, experimental, and modeling study of arsenic partitioning across a redox transition in a Bangladesh aquifer. Environ. Sci. Technol. 46, $1388-1395$.

Le, X.C., Ma, M., 1998. Short-column liquid chromatography with hydride generation atomic fluorescence detection for the speciation of arsenic. Anal. Chem. 70, 1926-1933.

Leckie, D.A., Bhattacharya, J.P., Bloch, J., Gilboy, C.F., Norris, B., 1994. Cretaceous Colorado/Alberta Group of the Western Canada Sedimentary Basin. Chapter 20, Geological Atlas of the Western Canada Sedimentary Basin, pp. 335-352. 
Lemay, T.G., 2003. Arsenic concentrations in Quaternary drift and Quaternary-Tertiary buried channel aquifers in the Athabasca Oil Sands (in situ) Area, Alberta. Alberta Energy and Utilities Board, Alberta Geological Survey, Geo-Note 2002-04.

Lemay, T., Parks, K., Andriashek, L.D., Michael, K., Jean, G., Kempin, E. Stewart, S., 2005. Regional Groundwater Quality Appraisal, Cold Lake-Beaver River Drainage Basin, Alberta. Alberta Geological Survey Special Report 73.

Leybourne, M.I, Johannesson, K.H., Asfaw, A., Measuring arsenic speciation in environmental media: sampling, preservation, and analysis. In: Bowell, R.J., Alpers, C.N., Jamieson, H.E., Nordstrom, D.K., Majzlan, J., (Eds.), Arsenic: Environmental Geochemistry, Mineralogy, and Microbiology. Rev. Mineral. Geochem. 79, 371-390.

Lovley, D.R., 1987. Organic matter mineralization with the reduction of ferric iron: a review. Geomicrobiol. J. 5, 375-399.

Majzlan, J., Drahota, P., Filippi, M., 2014. Parageneses and crystal chemistry of arsenic minerals. In: Bowell, R.J., Alpers, C.N., Jamieson, H.E., Nordstrom, D.K., Majzlan, J., (Eds.), Arsenic: Environmental Geochemistry, Mineralogy, and Microbiology. Rev. Mineral. Geochem. 79, 17-184.

Manning, B. A., and Goldberg, S., 1996. Modeling competetive adsorption of arsenate with phosphate and molybdate on oxide minerals. Soil Sci. Soc. Am. J. 60, 121-131.

Mattu, G., Schreier, H., 2000. An investigation of high arsenic levels in wells in the Sunshine Coast and Powell River regions of B.C. Report prepared for the Coast Garibaldi Community Health Services Society.

Mayer, B., 2005. Assessing sources and transformations of sulfate and nitrate in the hydrosphere using isotope techniques. In: Aggarwal, P.K., Gat, J.R., Froehlich, K.F.O., (Eds.), Isotopes in the Water Cycle: Past, Present and Future of a Developing Science. International Atomic Energy Agency, Springer, Dordrecht, Netherlands, p. 67-89.

McCreadie, H., Blowes, D.W., Ptacek, C.J., Jambor, J.L., 2000. Influence of reduction reactions and solid-phase composition on porewater concentrations of arsenic. Environ. Sci. Technol. 34, 3159- 66.

McGuigan, C.F., Hamula, C.L.A., Huang, S., Gabos, S., Le, C., 2010. A review on arsenic concentrations in Canadian drinking water. Environ. Rev. 18, 291-307.

Meranger, J.C., Subramanian, K.S., 1984. Arsenic in Nova Scotia groundwater. Sci. Tot. Environ. 39, 49-55.

Mitchell, V.L., 2014. Health risks associated with chronic exposures to arsenic in the environment. In: Bowell, R.J., Alpers, C.N., Jamieson, H.E., Nordstrom, D.K., Majzlan, 
J., (Eds.), Arsenic: Environmental Geochemistry, Mineralogy, and Microbiology. Rev. Mineral. Geochem. 79, 435-450.

Moore, K., 2005. Treatment of Arsenic Contaminated Groundwater using Oxidation and Membrane Filtration. MSc. Thesis, University of Waterloo, Waterloo, ON.

Moncur, M.C., Ptacek, C.J., Blowes, D.W., Jambor J.L. 2005. Release, transport, and attenuation of metals from an old tailings impoundment. Appl. Geochem., 20, 639-659.

Moncur, M.C., 2010. Uranium anomalies in shallow groundwater near Bonnyville, Alberta. Water for Life: Knowledge and Research Series. ISBN No. 978-0-7785-9952-4.

Mukherjee, A., Scanlon, B.R., Fryar, A.E., Saha, D., Ghosh, A., Chowdhuri, S., Mishra, R., 2012. Solute chemistry and arsenic fate in aquifers between the Himalayan foothills and Indian craton (including central Gangetic plains): influence of geology and geomorphology. Geochim. Cosmochim. Acta 90, 283-302.

Mumford, A.C., Barringer, J.L., Benzel, W.M., Reilly, P.A., Young, L.Y., 2012. Microbial transformations of arsenic: mobilization from glauconitic sediments to water. Wat. Res. 46, 2859-2868.

Munk, L., Hagedorn, B., Sjostrom, D., Seasonal fluctuations and mobility of arsenic in groundwater resources, Anchorage, Alaska. Appl. Geochem. 26, 1811-1817.

Nickson, R.T., McArthur, J.M., Ravenscroft, P., Burgess, W.G., Ahmed, K.M., 2000. Mechanisms of arsenic release to groundwater, Bangladesh and West Bengal. Appl. Geochem. 15, 403-13. Nordstrom D. K., 1982. Aqueous pyrite oxidation and the consequent formation of secondary iron minerals. In: Kittrick, J.A., Fanning, D.F., Hossner, L.R. (Eds.), Acid Sulfate Weathering, Soil Sci. Soc. Am. Spec. Publ. 10, p. 37 56.

Nordstrom, D.K., 2002. Worldwide occurrence of arsenic in ground water. Sci. 21, 2143-2145.

Nordstrom, D.K., 2012. Arsenic in the geosphere meets the anthroposphere. In: Ng, J.C., Noller, B.N., Naidu, R., Bundschuh, J., Bhattacharya, P., (Eds.), Proceedings of the $4^{\text {th }}$ International Congress on Arsenic in the Environment, CRC Press, p. 15-19

Nriagu, J.O., 1998. Arsenic in groundwater in the Cold Lake area. Sessional Paper 560199.

Paktunc, D., Foster, A., Heald, S., Laflamme, G., 2004. Speciation and characterization of arsenic in gold ores and cyanidation tailings using X-ray absorption spectroscopy. Geochim. Cosmochim. Acta 68, 969-983.

Paktunc, D., 2004. A computer program for analysing complex bulk XAFS spectra and for performing significance tests. J. Synchrotron Rad. 11, 295-298. 
Paktunc, D., 2008. Speciation of arsenic in pyrite by micro-X-ray absorption fine- structure spectroscopy (XAFS). Proc. 9th Int. Cong. App. Mineral. (ICAM2008) 8-10 September 2008, Brisbane, Queensland, Australasian Inst. Mining Metall., 155-158.

Paktunc, D., Dutrizac, J. Gertsman, V., 2008. Synthesis and phase transformations involving scorodite, ferric arsenate and arsenical ferrihydrite: Implications for arsenic mobility. Geochim. Cosmochim. Acta 72, 2649-2672.

Paktunc, D., 2013. Mobilization of arsenic from mine tailings through reductive dissolution of goethite influenced by organic cover. Appl. Geochem. 36, 49-56.

Parkhurst, D.L., Appelo, C.A.J., 1999. User's guide to PHREEQC (version 2) - a computer program for speciation, batch-reaction, one-dimensional transport, and inverse geochemical calculations. US Geol. Survey, Water-Resour. Inv. Rep. 99-4259, pp. 312.

Parkhurst, D.L., Charlton, S.R., 2008. NetpathXL - an Excel interface to the program NETPATH: U.S. Geological Survey Techniques and Methods 6-A26, p. 11.

Parks, K., Andriashek, L.D., Michael, K., Lemay, T., Stewart, S., Jean, G., Kempin, E., 2005. Regional Groundwater Resource Appraisal, Cold Lake-Beaver River Drainage Basin, Alberta. Alberta Geological Survey Special Report 74.

Plummer, L.N., Prestemon, E.C., Parkhurst, D.L., 1994. An interactive code (NETPATH) for modeling NET geochemical reactions along a flow PATH, version 2.0: U.S. Geological Survey Water-Resources Investigations Report 94-4169. p. 130.

Prior, G.J., Hathway, B., Glombick, P.M., Pană, D.I., Banks, C.J., Hay, D.C., Schneider, C.L., Grobe, M., Elgr, R., Weiss, J.A., 2013. Bedrock geology of Alberta. Alberta Energy Regulator, AER/AGS Map 600, scale 1:1 000000.

Puls, R.W., Barcelona, M.J., 1996. Low-flow (minimal drawdown) ground-water sampling procedures. USEPA Ground Water Issue, EPA/540/S-95/504, pp. 11.

Rageh, O.M, Coles, C.A., Lye, L.M., 2007. Statistical analysis of Newfoundland drinking water sources containing arsenic. In Ottawa Geo2007 $-60^{\text {th }}$ Canadian Geotechnical Conference, $8^{\text {th }}$ CGS/IAH-CHC Groundwater Conference, Ottawa, ON, pp. 2287-2291

Ravel, B., Newville, M., 2005. ATHENA, ARTEMIS, HEPHAESTUS: data analysis for X-ray absorption spectroscopy using IFEFFIT. J. Synchrotron Rad. 12, 537-541.

Ravenscroft, P., Howarth, R.J., McArthur, J.M., 2006. Comment on "Limited temporal variability of arsenic concentrations in 20 wells monitored for 3 years in Araihazar, Bangladesh”. Environ Sci. Technol. 40, 1716-1717. 
Rokosh, C.D., Pawlowicz, J.G., Berhane, H., Anderson, S.D.A., Beaton, A.P., 2009. Geochemical and sedimentological investigation of the Colorado Group for shale gas potential: initial results. ERCB/AGS Open File Report 2008-09.

Ross, C.S., Bain, J.G., Blowes, D.W., 1999. Transport and attenuation from a gold mine tailings impoundment. In: Goldsack, D.E., Belzile, N., Yearwood, P., Hall, G.J., (Eds.), Sudbury '99, Mining and the Environment II, Vol. 2., pp. 745-754.

Serpa, C., Batterson, M., Guzzwell, K., 2009. The influence of bedrock and mineral occurrences on arsenic concentrations in groundwater wells in the Gander Bay Area, Newfoundland. Newfoundland and Labrador Department of Natural Resources Geological Survey, Report 09-1, pp. 315-337.

Smedley, P.L., Kinniburgh, D.G., 2002. A Review of the source, behaviour and distribution of arsenic in natural waters. Appl. Geochem. 17, 517-568.

Somers, G., Raymond, B., Uhlman, W., 1999. P.E.I. Water Quality Interpretive Report. Repot prepared for the Canada - Prince Edward Island Water Annex.

Stein, R., Dudas, M., Klebek, M., 2000. Occurrence of arsenic in groundwater near Cold Lake, Alberta. Alberta Environment.

Thompson, T.S., Le, M.D., Kasick, A.R., Macaulay, T.J., 1999. Arsenic in well water supplies in Saskatchewan. Bull. Environ. Contam. Toxicol. 63, 478-483.

Tu, Q., Schröder-Adams, C.J., Craig, J., 2007. A New Lithostratigraphic Framework for the Cretaceous Colorado Group in the Cold Lake Heavy Oil Area, East-Central Alberta, Canada. Nat. Resour. Res. 16, 17-30.

Tuttle, J.H., Dugan, P.R., Randles, C.I., 1969. Microbial sulfate reduction and its potential utility as an acid mine water pollution abatement procedure. Appl. Microbiol. 17, 297-302.

van Green, A., Zheng, Y, Goodbred Jr., S, Horneman, A., Aziz, Z., Cheng, Z., Stute, M., Mailloux, B., Weinman, B., Hoque, M.A., Seddique, A.A., Hossain, M.S., Chowdhury, S.H., Ahmed, K.M., 2008. Flushing history as a hydrogeological control on the regional distribution of arsenic in shallow groundwater of the Bengal basin. Environ. Sci. Technol. 42, 2283-2288.

van Halem, D., Bakker, S.A., Amy, G.L., van Dijk, J.C., 2009. Arsenic in drinking water: a worldwide water quality concern for water supply companies. Drink. Water Eng. Sci. 2, 29-34.

Wang, S., Mulligan, C., 2006. Occurrence of arsenic contamination in Canada: sources, behavior and distribution. Sci. Total Environ. 366, pp. 701-721. 
White, D.E., Hem, J.D., Waring, G.A., 1963. Data of Geochemistry, $6^{\text {th }}$ ed. M. Fleischer, (Ed). Chapter F. Chemical Composition of Sub-Surface Waters. US Geol. Surv. Prof. Pap. 440F.

Windsor Star, 2006, May 11. Town groundwater tainted by arsenic. Accessed April 14, 2014. http://www.canada.com/story_print.html?id=92734581-cf0b-4a17-afeb$\underline{\mathrm{fb} 205368685 \mathrm{f} \& \text { sponsor. }}$

Yan, X.P., Kerrich, R., Hendry, M.J., 2000. Distribution of arsenic(III), arsenic(V) and total inorganic arsenic in porewaters from a thick till and clay-rich aquitard sequence, Saskatchewan, Canada. Geochim.Cosmochim. Acta 64, 2637-48.

Zagury, G.J., Samson, R., Deschênes, L., 2003. Occurrence of metals in soil and ground water near chromated copper arsenate-treated utility poles. J. Eviron. Qual. 32, 507-514.

Zobrist, J., Dowdle, P.R., Davis, J.A., Oremland, R.S., 2000. Mobilization of arsenite by dissimilatory reduction of adsorbed arsenate. Environ. Sci. Technol. 34, 4747-4753. 